\title{
Ground-Water Resources of The Pascagoula River Basin Mississippi and Alabama
}

GEOLOGICAL SURVEY WATER-SUPPLY PAPER 1839-K

Prepared in cooperation with the Mobile District, Corps of Engineers, U.S. Army

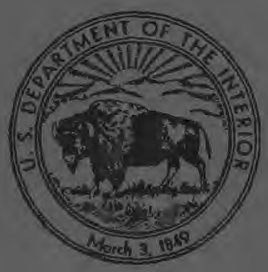




\section{Ground-Water Resources of The Pascagoula River Basin Mississippi and Alabama}

By ROY NEWCOME, JR.

CONTRIBUTIONS TO THE HYDROLOGY OF THE UNITED STATES

GEOLOGICAL SURVEY WATER-SUPPLY PAPER 1839-K

Prepared in cooperation with the Mobile District, Corps of Engineers, U.S. Army A general description of ground-water availability, quantity, and quality in a major river basin of the $G$ ulf Coast region

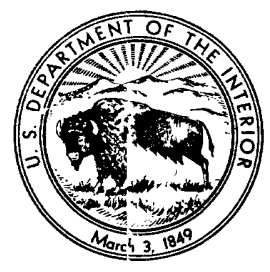




\section{UNITED STATES DEPARTMENT OF THE INTERIOR}

STEWART L. UDALL, Secretary

\section{GEOLOGICAL SURVEY}

William T. Pecora, Director 


\section{CONTENTS}

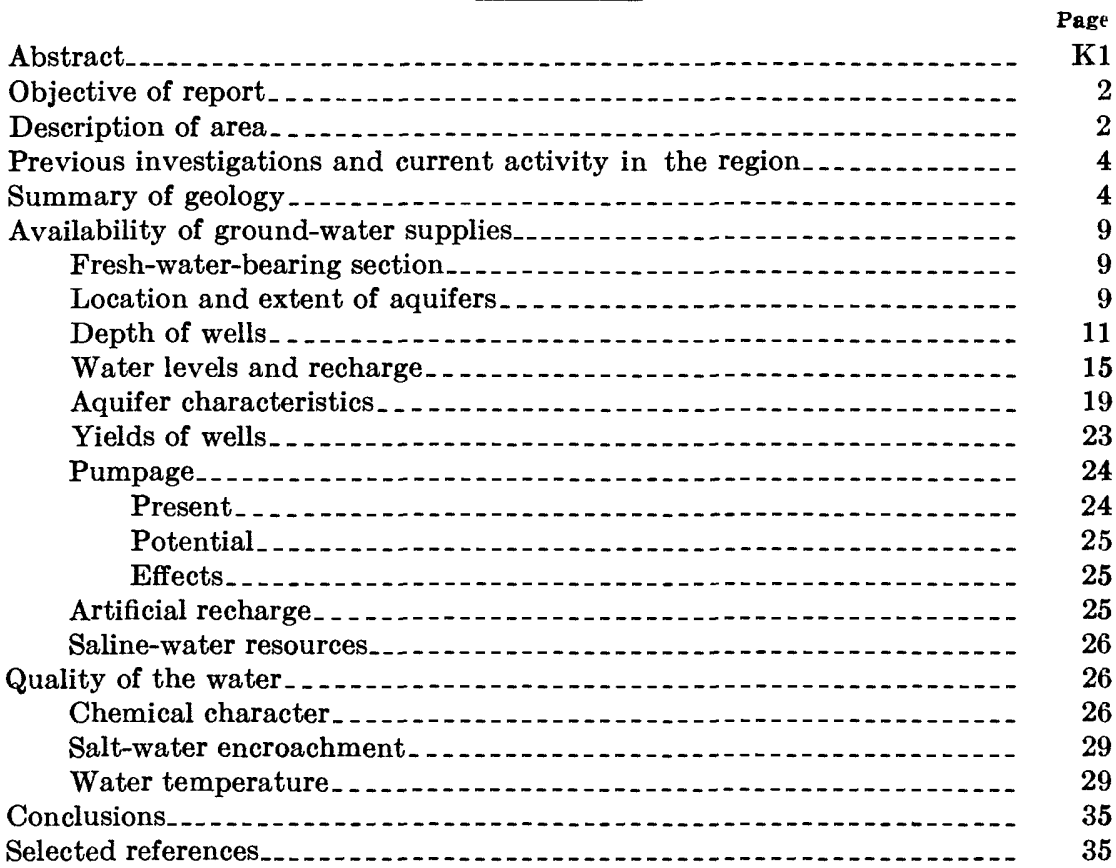

\section{ILLUSTRATIONS}

Figure 1. Map showing location and major drainage

2. Fence diagram

3-6. Map showing-

3. Configuration of the top of Moodys Branch Formation or equivalent

4. Configuration of the base of fresh water...... 12

5. Distribution of fresh-water aquifers............. 13

6. Location of oil tests........ 14

7. Sections $A^{\prime}-A^{\prime}$ and $B^{\prime}-B^{\prime}$ based on electric logs........ 17

8. Hydrographs showing water-level trends in selected observation wells.

9. Graph of transmissibility-drawdown-yield relation

10. Graph of time-drawdown relations

11. Map showing configuration of the top of the saline-waterresource zone.

12. Map showing location of water-sampling sites........ 


\section{TABLES}

Table 1. Stratigraphic units in the Pascagoula River basin end their water-bearing character.

2. Fresh-water sand intervals in the Pascagoula River kasin.... 10

3. Aquifer characteristics determined from pumping tests in and near the Pascagoula River basin....

4. Chemical analyses of water from wells in the Prscagoula
River basin. 


\title{
GROUND-WATER RESOURGES OF THE PASGAGOULA RIVER BASIN, MISSISSIPPI AND ALABAMA
}

\author{
By Roy Newcome, Jr.
}

\section{ABSTRACT}

Abundant ground-water resources underlie the Pascagoula Rirer basin. These resources have been dereloped intensively in only a few places-namely, Hattiesburg, Laurel, Meridian, and Pascagoula. Seepage from the ground water reservoirs sustains the base flows of the Leaf, Chickasawhay, Pascagoula, and Escatawpa Rivers and their tributaries.

The fresh-water-bearing section is 300 to 3,500 feet thick and is composed chiefly of sand and clay of Eocene to Recent age. Major rock units represented are the Wilcox, Claiborne, Jackson, and Vicksburg Groups and formations of Miocene and Pliocene ages.

Aquifers in the Claiborne Group provide water for all purposes in the northern third of the basin. The Claiborne is underlain by the potentially important but virtually untapped Wilcox Group. Miocene aquifers are the main sorrce of water supplies in the southern half of the basin, but Pliocene aquifers furnish most supplies in the Jackson County area at the basin's southern extremity.

Much of the fresh-water section has undergone no water-supply development because of the great depth of many aquifers and the availability, at shallow depths, of supplies adequate for present needs. However, a large part of any substantial increase in ground-water withdrawal will probably come from wells deeper than those commonly drilled in the region.

Ground-water levels are within 50 feet of the surface in most places, and flowing wells are common in the valleys and near the coast. Water-lerel declines due to pumping have become serious problems only in a few localities of heavy withdrawal. In most of these places redistribution of pumpage would alleviate the problem of excessive drawdown.

Although few wells in the basin yield more than $\mathbf{5 0 0}$ gallons per minute, yields of 2,000 gallons per minute or more could be reasonably expected from efficiently constructed wells almost anywhere in the region.

Total ground-water pumpage is estimated to be about 60 million gallons per day. Potential pumpage is many times that figure. Well fields caprble of yielding several million gallons of water per day would be feasible in most places.

The ground water is of good to excellent quality. Most of it is a sodium bicarbonate type of water. It usually is soft and has a low to moderste dissolved-solids content. Excessive iron is a problem in places, particularly where 
water supplies are obtained from shallow aquifers, but at least a part of the excess iron comes from corrosion of well and distribution-line fittings by slightly acidic water.

Salt-water encroachment is a potential problem in the coastal area, but little increase in salinity has been observed in monitor wells in the period 1960-65. Saline-water resources are available for development at considerable depth in most of the region.

\section{OBJECTIVE OF REPORT}

This report, describing the geology and ground-wat $\sim r$ resources of the Pascagoula River basin, was prepared at the request of the Corps of Engineers, U.S. Army, as part of a comprehensive program to appraise the resources of selected river basins The ultimate purpose of the program is to present facts that will lead to optimum development of the natural and cultural resources of large areas constituting the river basins. Other basin studie underway in Mississippi are for the Big Black and Pearl Rivers.

In scope this report deals with the major aspects of ground-water occurrence and development and their interrelation with the geology of the selected region. No attempt is made to give detailed descriptions of specific localities or even of counties; that effort is reserved for future investigations.

\section{DESCRIPTION OF AREA}

Most of southeastern Mississippi and a small part of southwestern Alabama are included in the Pascagoula River basin (fig. 1). The basin contains all or parts of 22 counties in Mississippi and parts of 3 counties in Alabama; the total area is about 9,700 scuare miles.

Landforms in the basin consist of low rounded hills, stream flood plains, and coastal flats. Elevations range from sea level to about 700 feet. Local topography is rugged in the northeast. corner of the basin, but gently rolling to flat in the remainder of $t$ ths area.

Major streams, in addition to the Pascagoula River, are the Leaf, Chickashawhay, and Escatawpa Rivers. The subbasins drained by these streams are shown on the location map (fig. 1). Average discharge of the Pascagoula River at Merrill is 9,587 cfs (cubic feet per second). Minimum flow is $696 \mathrm{cfs}$ and maximum is $178,000 \mathrm{cfs}$. Average flows of the larger tributary streams are Leaf River at Hattiesburg, 2,608 cfs; Chickasawhay River at Leakesville, 3,711 cfs; and Escatawpa River near Wilmer, Ala., 1,003 cfs (U.S. Geological Survey, 1964). Base flows of the streams are sustained by ground-water discharge.

Average annual precipitation in the Pascagoula Fiver basin ranges from 50 to 64 inches, depending on geographic location. Average annual precipitation for the basin is 57 inches. 


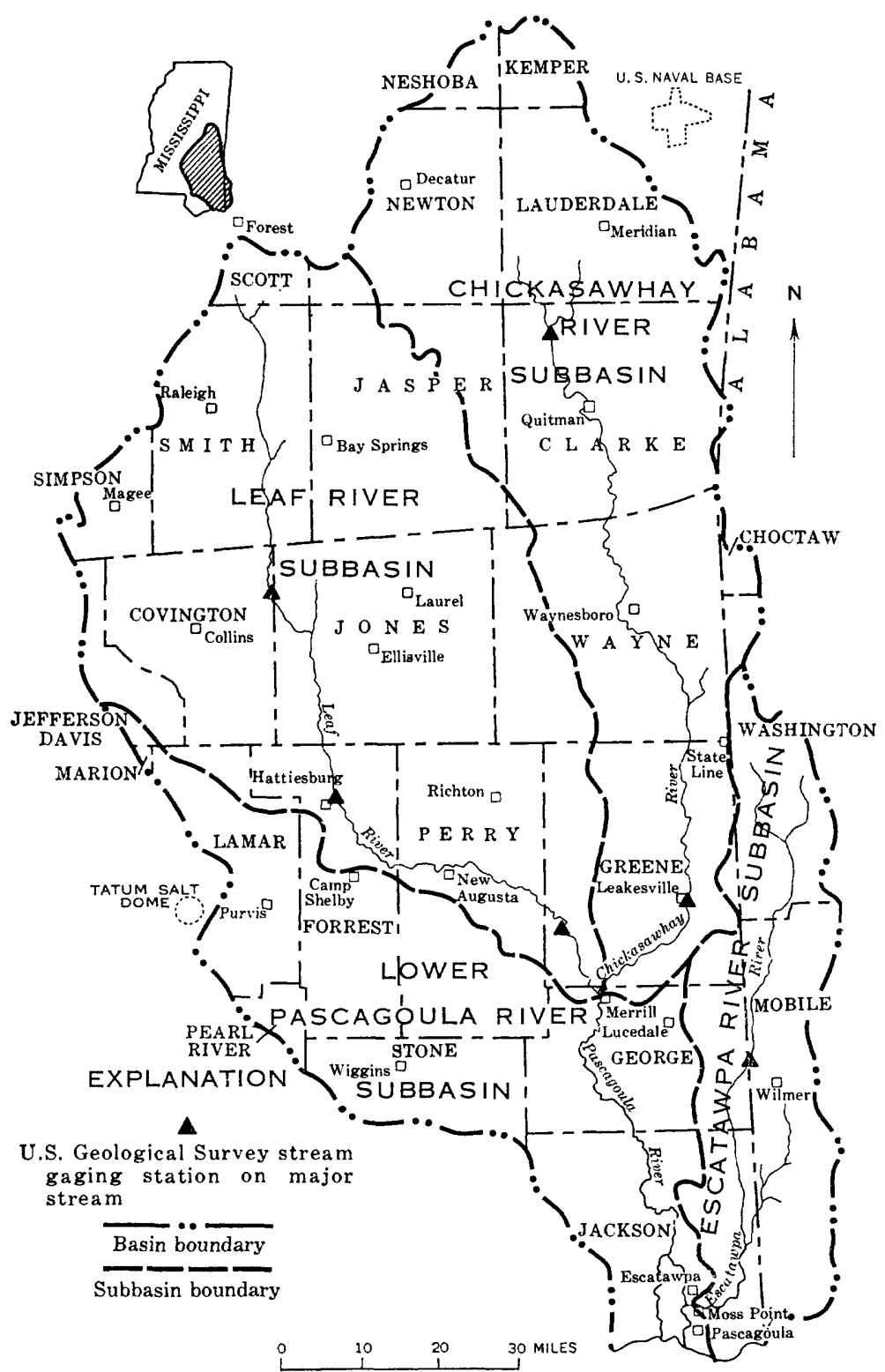

FIgURE 1.-Location and major drainage of the Pascagoula River basin. 
The average annual temperature is $66^{\circ} \mathrm{F}$, about the same as the temperature of ground water in shallow aquifers. Temperature extremes are $+110^{\circ}$ and $-10^{\circ} \mathrm{F}$. The growing season averages 222 days between late March and early November, except in the immediate vicinity of the coast where the time between killing frosts may be as much as 290 days.

\section{PREVIOUS INVESTIGATIONS AND CURRENT A CTIVITY IN THE REGION}

The geology and water resources of all or parts of the Pascagoula River basin are described, in varying degree of detail, in the publications listed in the references at the end of the report.

Current water-resources investigations by the U.S. Geological Survey are under way in the Forrest-Perry-Greene-Jones-Wayne Counties area, in Lamar County (special study related to AEC testing at Tatum dome), and in the Jackson-George Counties area.

\section{SUMMARY OF GEOLOGY}

The Pascagoula River basin is in the Coastal Plain physiographic province. The basin is a topographic feature only and not a geologic entity. Exposed rock formations are sedimentart in origin and range in age from early Eocene to Recent (table 1). Sand and clay in various proportions constitute most of the formations; a few thin units consist of marl or limestone. Sand beds are irregular in thickness and few can be traced with certainty more than a few miles; however, sandy zones, as differentiated from clayey zones, are readily correlated over substantial areas-some throughout the basin.

The beds dip south-southwestward at 25 to 80 feet per mile. Dip is steepest across the southern half of Jackson County (fig. 2) where the weight of deltaic sediments that accumulated during the late part of the Tertiary Period caused the greatest downwarping. This downwarping becomes even more pronounced farther westward along the Gulf Coast toward the axis of the Mississippi River trough. The dip approaches 100 feet per mile in Hancock County.

The Moodys Branch Formation of late Eocene age is a thin but easily recognized marker bed underlying most of the Pascagoula River basin. A contour map (fig. 3) on this formation illustrates the general attitude of the formations in the region. 


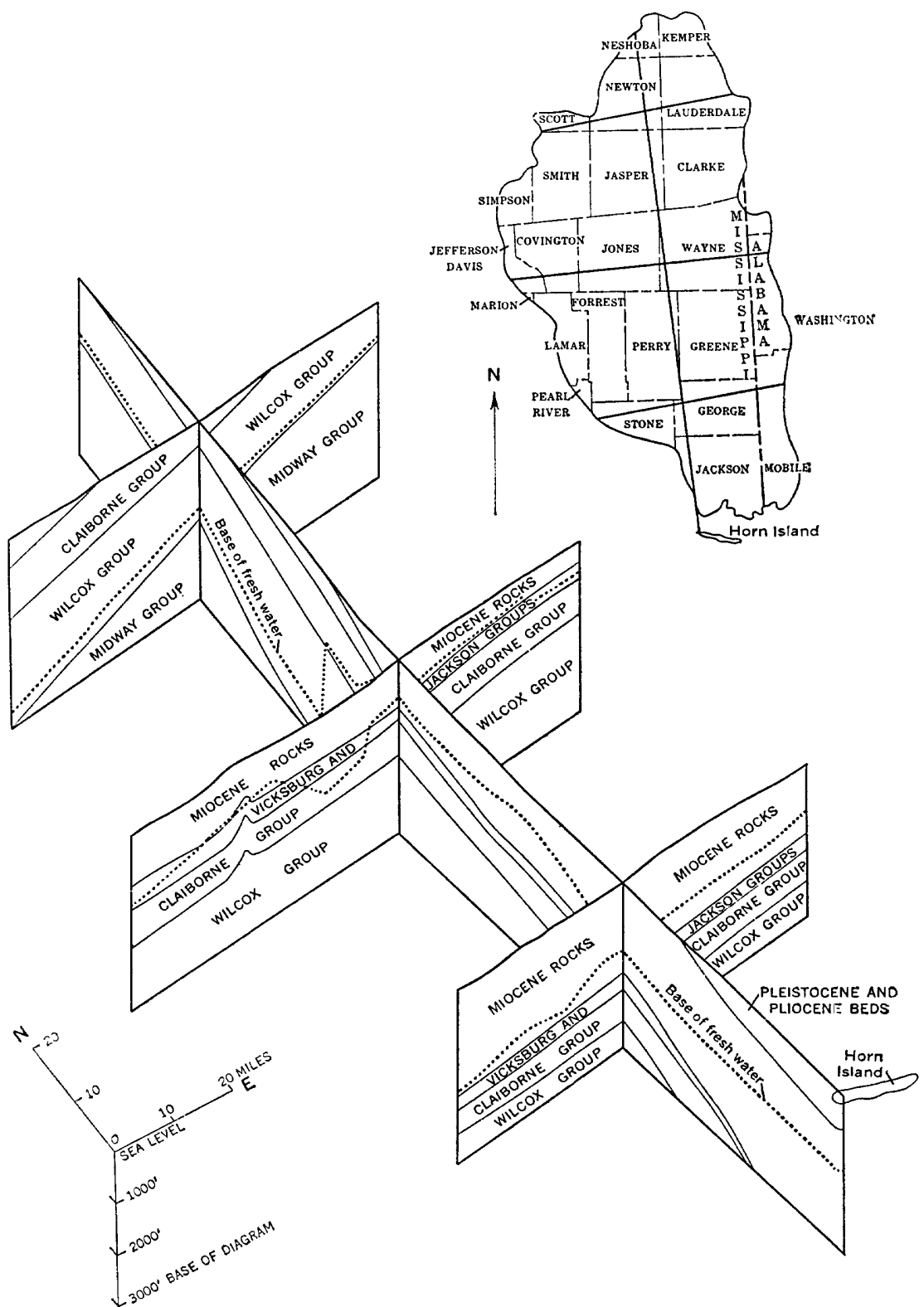

Figure 2.-Fence diagram of the Pascagoula River basin, Mississippi and Alabama. 


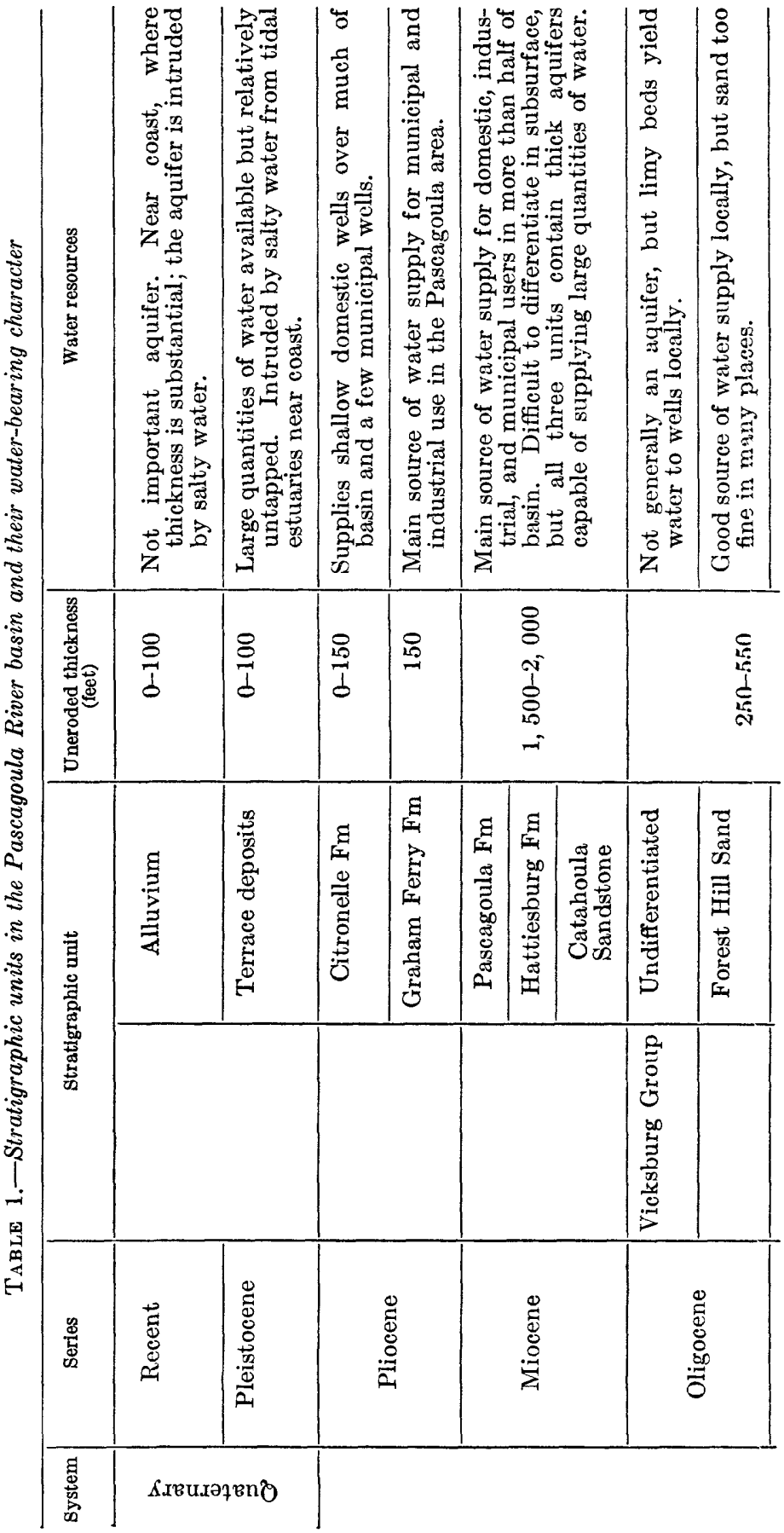




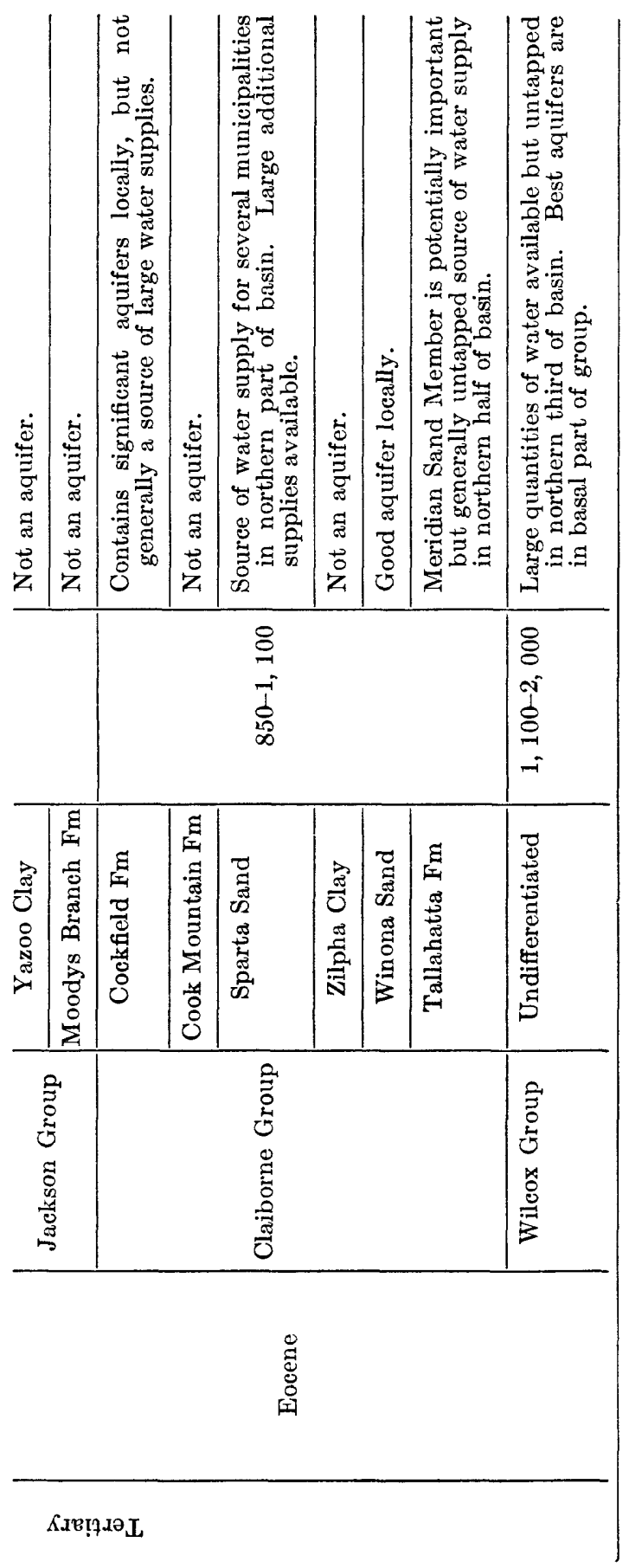




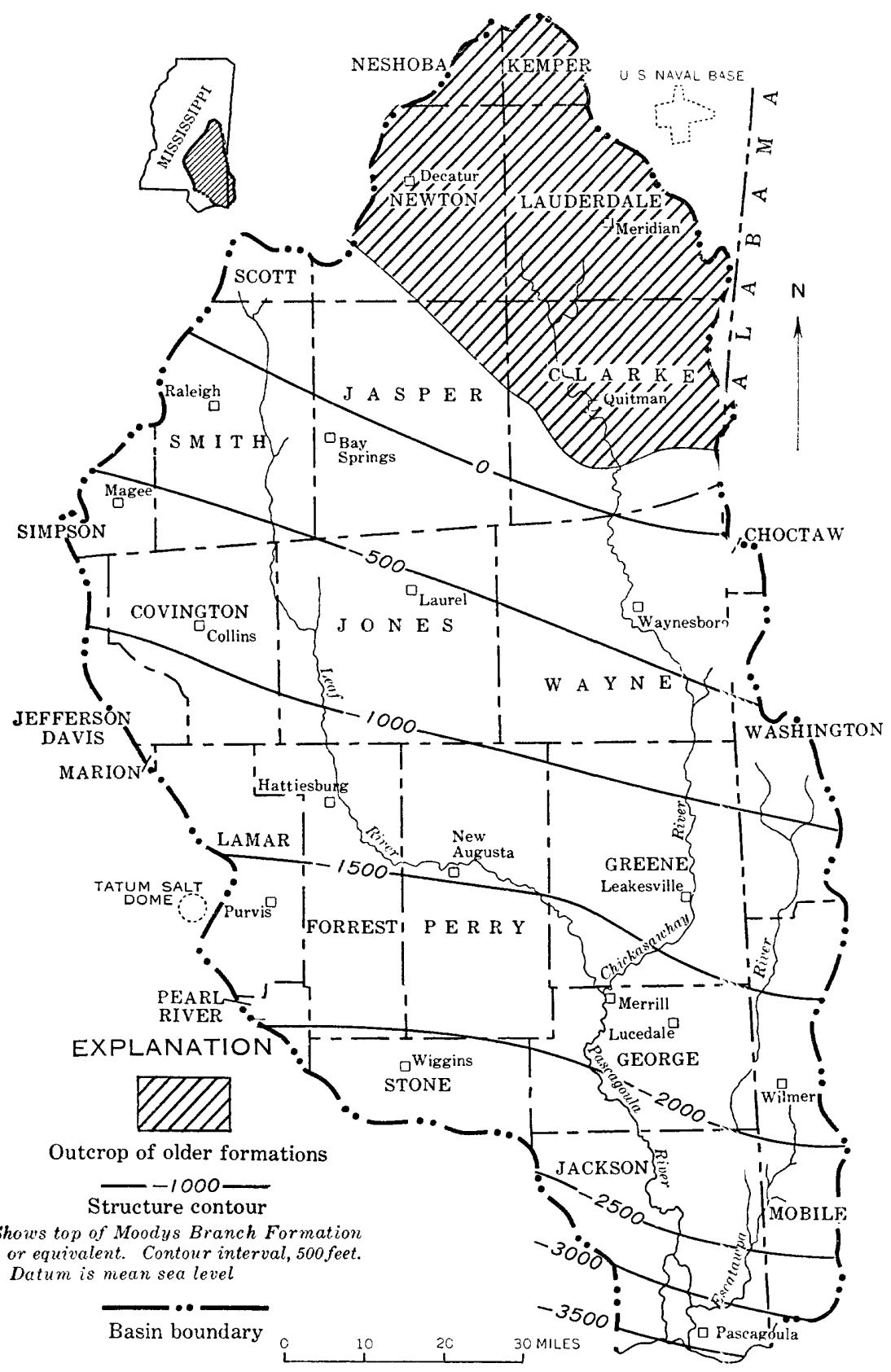

Fraure 3.-Configuration of the top of the Moodys Branch Formation or equivalent. 


\section{AVAILABILITY OF GROUND-WATER SUPPLIES}

\section{FRESH-WATER-BEARING SECTION}

Fresh ground water ${ }^{1}$ is available in the Pascalouga River basin to depths ranging from near sea level elevation on the northeast margin to more than 3,000 feet below sea level in the west-central part ( $f$ g. 4).

All the exposed formations of the basin are fresh-water bearing. The fresh-water section ranges in thickness from 300 to $3,50 \mathrm{C}$ feet. It is thinnest in the northeast and thickens southward into the $\$$ mithJasper-Wayne Counties area where fresh water extends farthest south in the basal part of the Wilcox Group. From this area southward the fresh-water section ranges between 1,900 and 700 feet in thickness. Greene and Perry Counties and southern Wayne County have $\varepsilon$, relatively thin fresh-water section restricted to rocks of Miocene age and younger.

\section{LOCATION AND EXTENT OF AQUIFERS}

A map of the general distribution of fresh ground water according to geologic units (fig. 5) shows that beds of Miocene age are sources of ground-water supplies throughout the southern two-thirds of the basin and are the only significant sources in about half of the basin.

The Claiborne Group furnishes practically all existing groundwater supplies in the northern third of the region. Although the underlying Wilcox Group occupies about 1,000 feet of the fresh-water section in that area, the Wilcox is virtually untapped for water supplies.

The Miocene and Wilcox beds generally do not contain fresh water in the same locality. Miocene and Claiborne aquifers, however, are both present in a band underlying the northern halves of Covington, Jones, and Wayne Counties. In this area nearly all water supplies are obtained from the shallower Miocene beds.

In Jackson County, Miss., and the southwestern part of Mobile County, Ala., fresh water can be obtained from geologic units of Pleistocene, Pliocene, and Miocene ages. The Pleistocene deposits are comparatively thin; most ground-water-supply development is in the underlying Pliocene beds, although the Miocene aquifers supply some municipal users.

Table 2 contains representative data obtained from electric logs of selected oil tests and water wells (fig. 6). These examples of freshwater sand intervals at various localities throughout the Pascagoula basin emphasize availability of the untapped ground-water resources. The relation of fresh-water sand zones across the basin is illustreted by electric-log sections $A-A^{\prime}$ and $B-B^{\prime}$ (fig. 7).

\footnotetext{
1 Fresh water is defined as water containing less than $1,000 \mathrm{ppm}$ (parts per million) of dissolved sollds.
} 
TABLE 2.-Fresh-water sand intervals in the Pascagoula River basin

[Data, in feet, from electric logs of oil test wells]

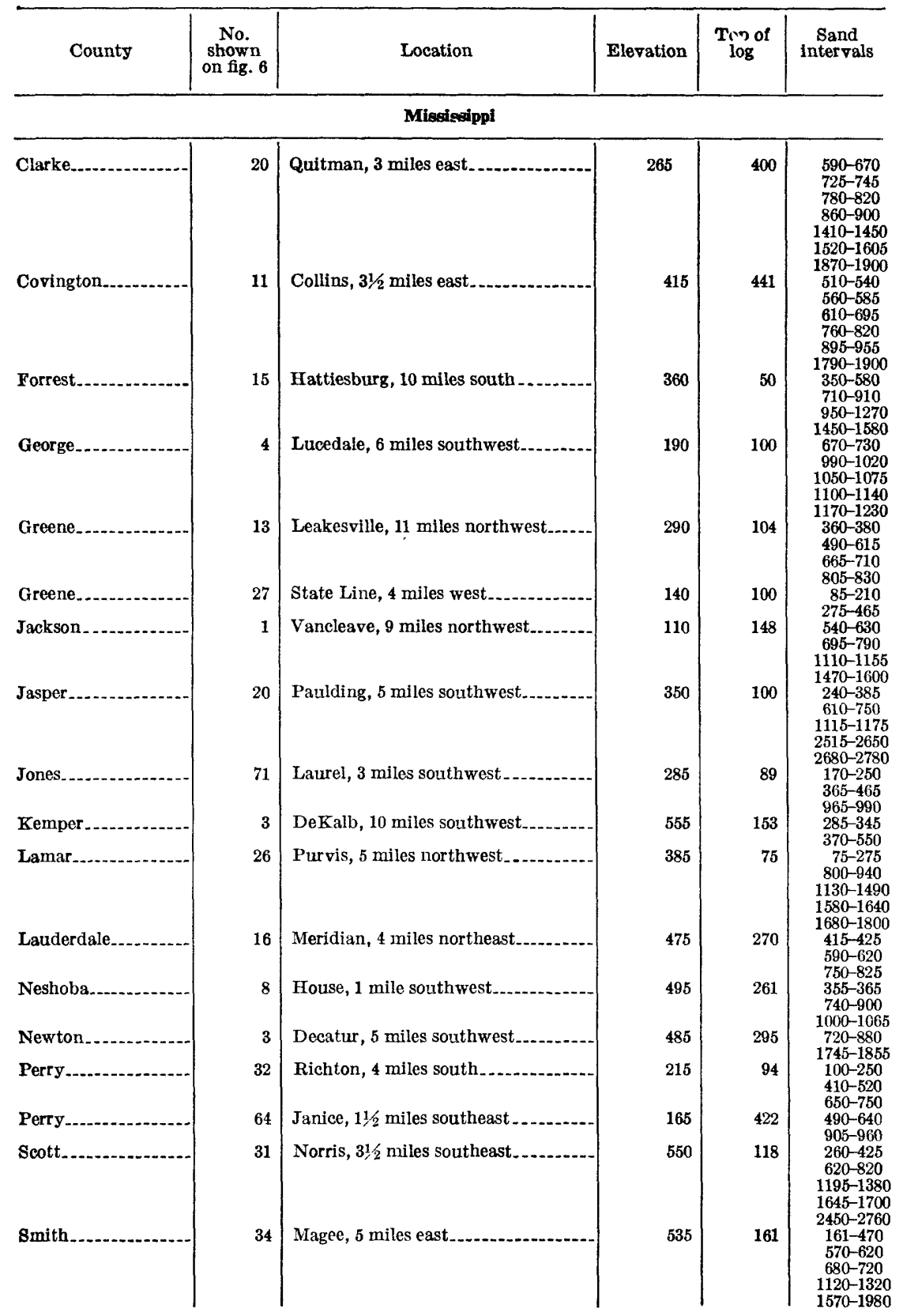


TABLE 2.-Fresh-water sand intervals in the Pascagoula River basin-Continued

[Data, in feet, from electric logs of oil test weils]

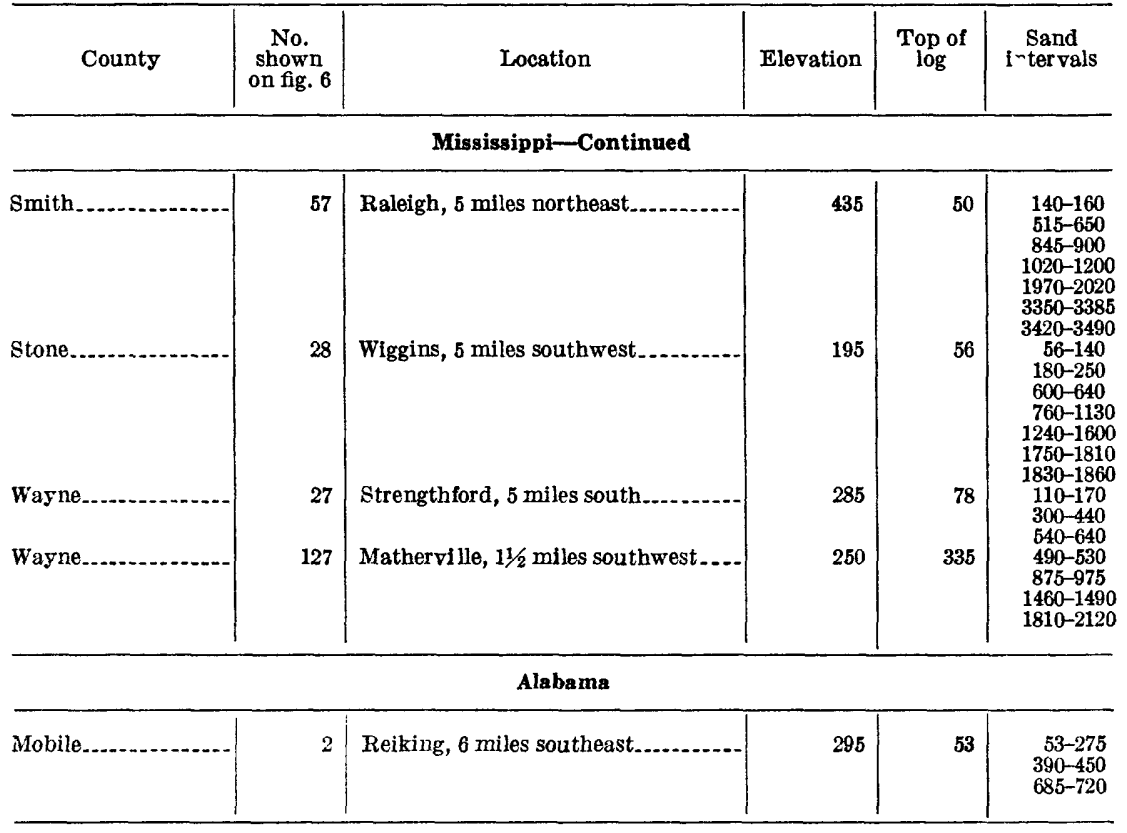

\section{DEPTH OF WELLS}

Drilled water wells in the Pascagoula basin range in deptr from about 50 feet to more than 1,000 feet. At least 60 percent of tha wells are less than 300 feet deep; however, the average depth of wells near the coast is greater than in the northern and central parts of the basin. The following table provides a statistical comparison of well depths for three counties representing the northern, central, and southern parts of the basin.

\begin{tabular}{|c|c|c|c|}
\hline \multirow[b]{2}{*}{ Well depth (ft) } & \multicolumn{3}{|c|}{ Percentage of wells } \\
\hline & $\begin{array}{c}\text { Lauderdale } \\
\text { County }\end{array}$ & $\begin{array}{l}\text { Jones } \\
\text { County }\end{array}$ & $\begin{array}{l}\text { Jackson } \\
\text { County }\end{array}$ \\
\hline $\begin{array}{l}\text { Less than } 100 \\
100-199 \\
200-299 \\
300-399 \\
400-499 \\
500-599 \\
800-799 \\
1,000 \text { and more }\end{array}$ & $\begin{array}{r}7 \\
26 \\
37 \\
18 \\
4 \\
0 \\
5 \\
2 \\
1\end{array}$ & $\begin{array}{r}27 \\
26 \\
25 \\
6 \\
7 \\
5 \\
1 \\
0 \\
3\end{array}$ & $\begin{array}{r}26 \\
12 \\
15 \\
13 \\
5 \\
6 \\
8 \\
10 \\
5\end{array}$ \\
\hline Number of wells used in computation & 271 & 161 & 687 \\
\hline
\end{tabular}




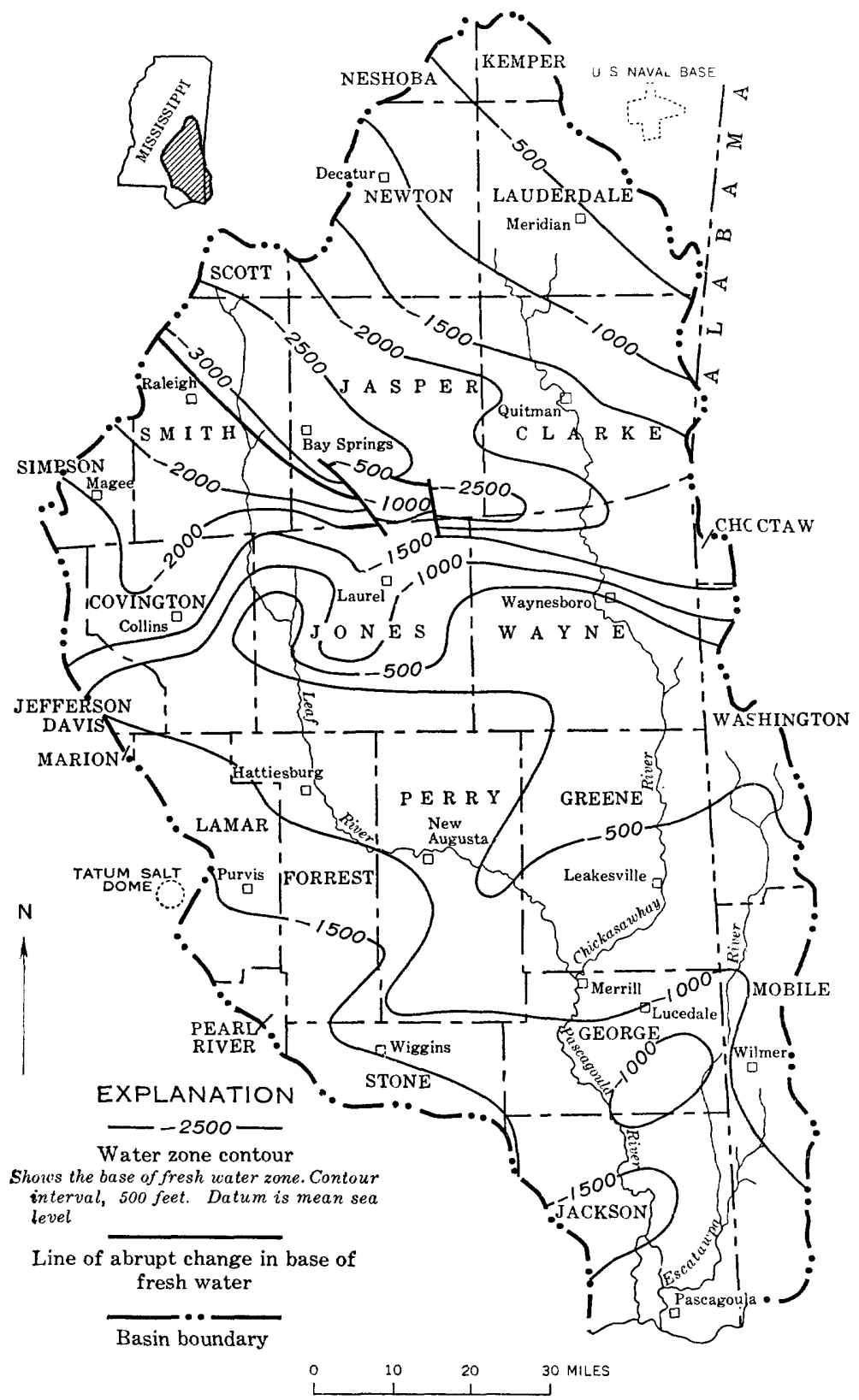

FIgURe 4.-Configuration of the base of fresh water. 


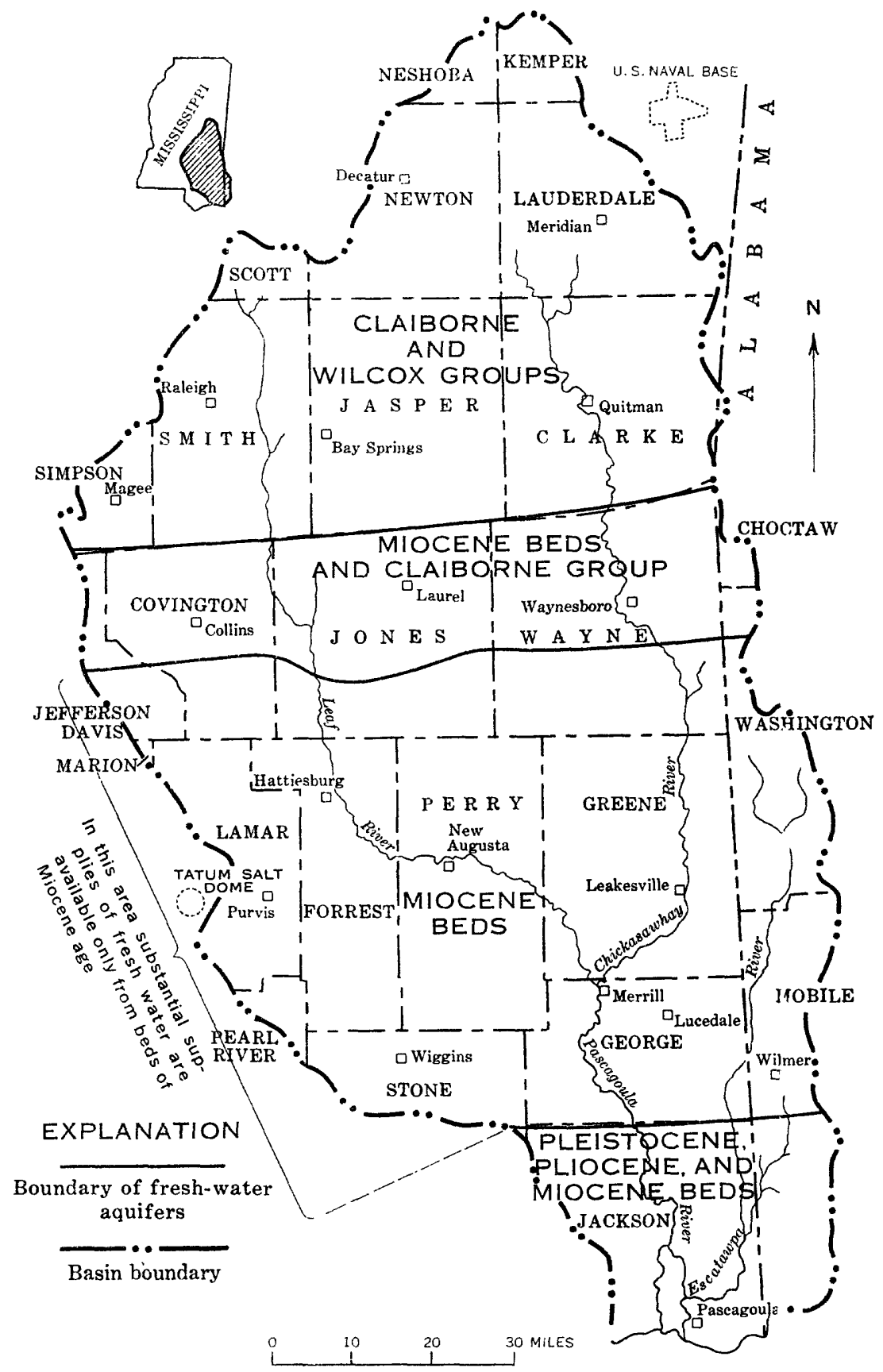

FIGURE 5.-Distribution of fresh-water aquifers. 


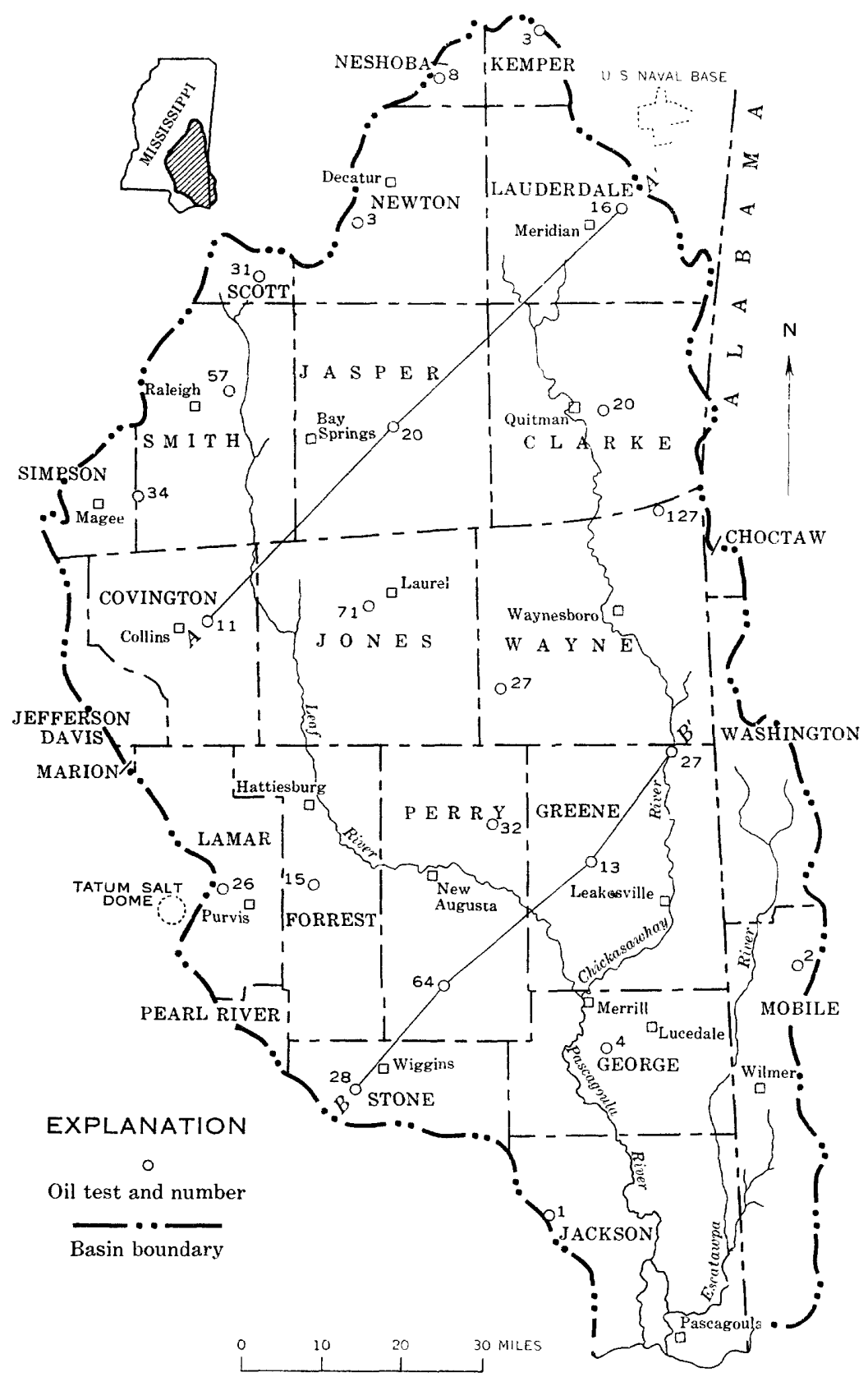

Fraure 6.-Location of oil tests used to determine thickness of fresh-water sands and to construct cross sections. See table 2 for thickness of sand intervals. Sections $A-A^{\prime}$ and $B-B^{\prime}$ are shown in figure 7 . 
There is little doubt that a large part of any substantial increase in ground-water withdrawal will come from wells deeper than those commonly drilled in the region. The great thickness of the fresh-water section and the massiveness of many of the deep-lying beds of sand invite exploration and development of these untapped sources of supply.

\section{WATER IEVELS AND RECHARGE}

Practically all drilled wells in the basin are artesian-that is, the water is under natural pressure and rises above the top of the aquifer when the aquifer is penetrated by a well. Nonpumping water levels are within 50 feet of the land surface in more than half the wells and within 200 feet of the surface in nearly all of them. A large percentage of the wells flow owing to a combination of hydrostatic rressure and low topographic position. The greater proportion of flowing wells is in the southern counties where the land is low and where the deeper wells tapping aquifers having greater artesian head are more ab'indant.

The same counties used to illustrate well-depth distribution are analyzed for water-level distribution.

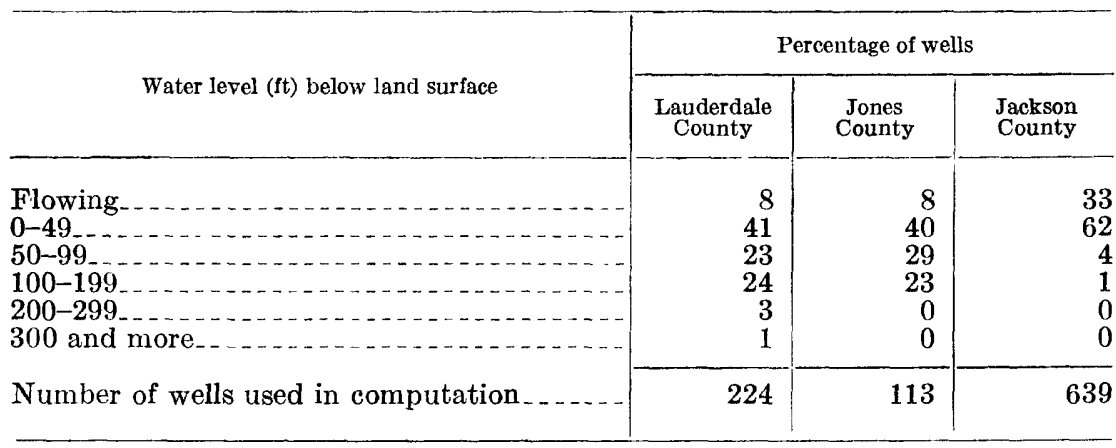

Ground-water levels are declining in many places in the basin. Declines take place at a slow rate (usually less than $1 \mathrm{ft}$ per yr) where they result only from land-use changes and low-rainful phases of the climatic cycle but at higher rates in areas of large withdrawal through wells. Hydrographs ( fig. 8) show water-level trends and the effect of changes in pumping on water levels.

In a few places, where substantial withdrawals are made, watersupply problems have arisen as a result of lowered water levels. Where feasible, the problems can be alleviated by redistribution of pumpage, either geographically or stratigraphically or a combination of the two. 


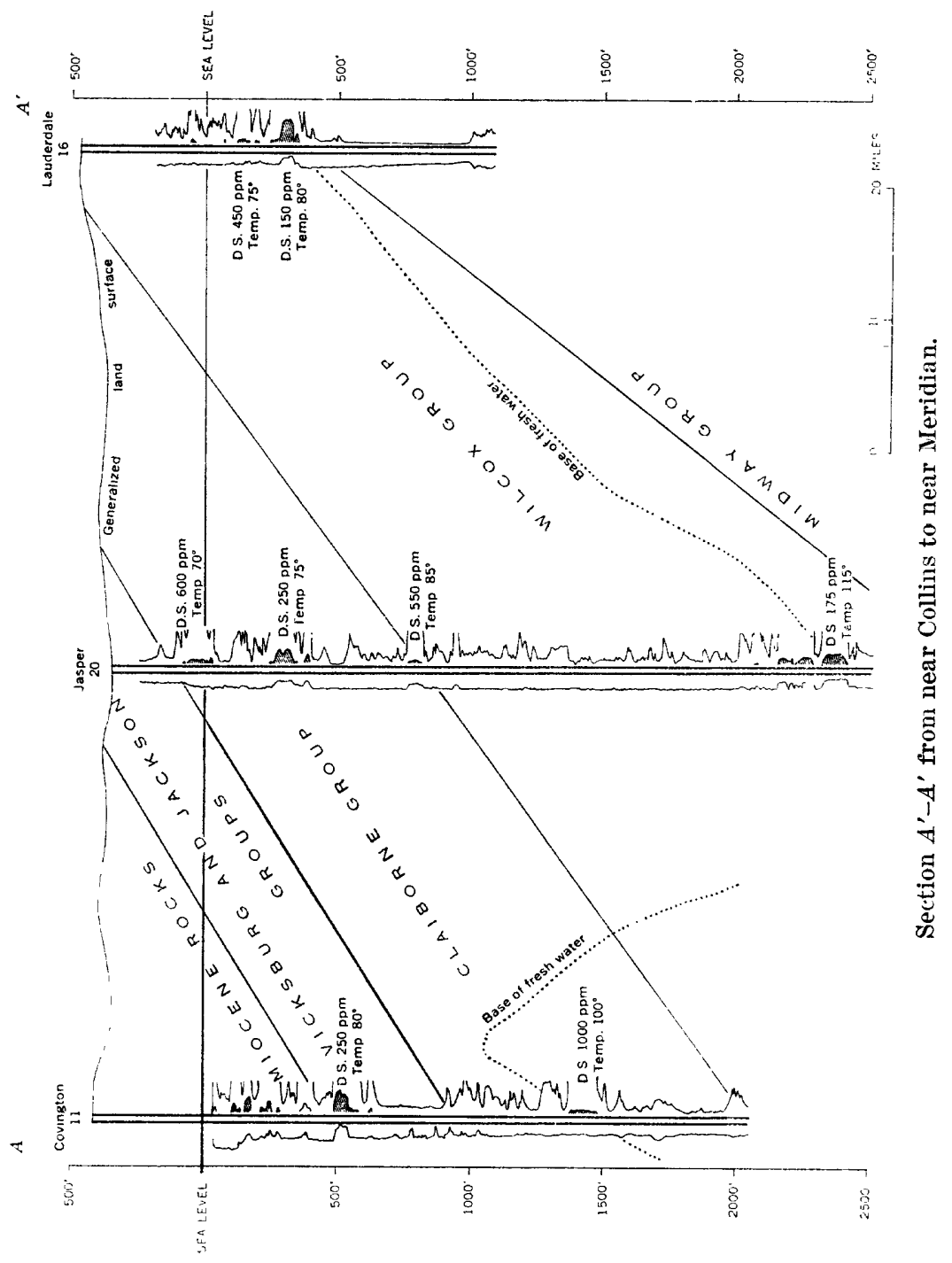




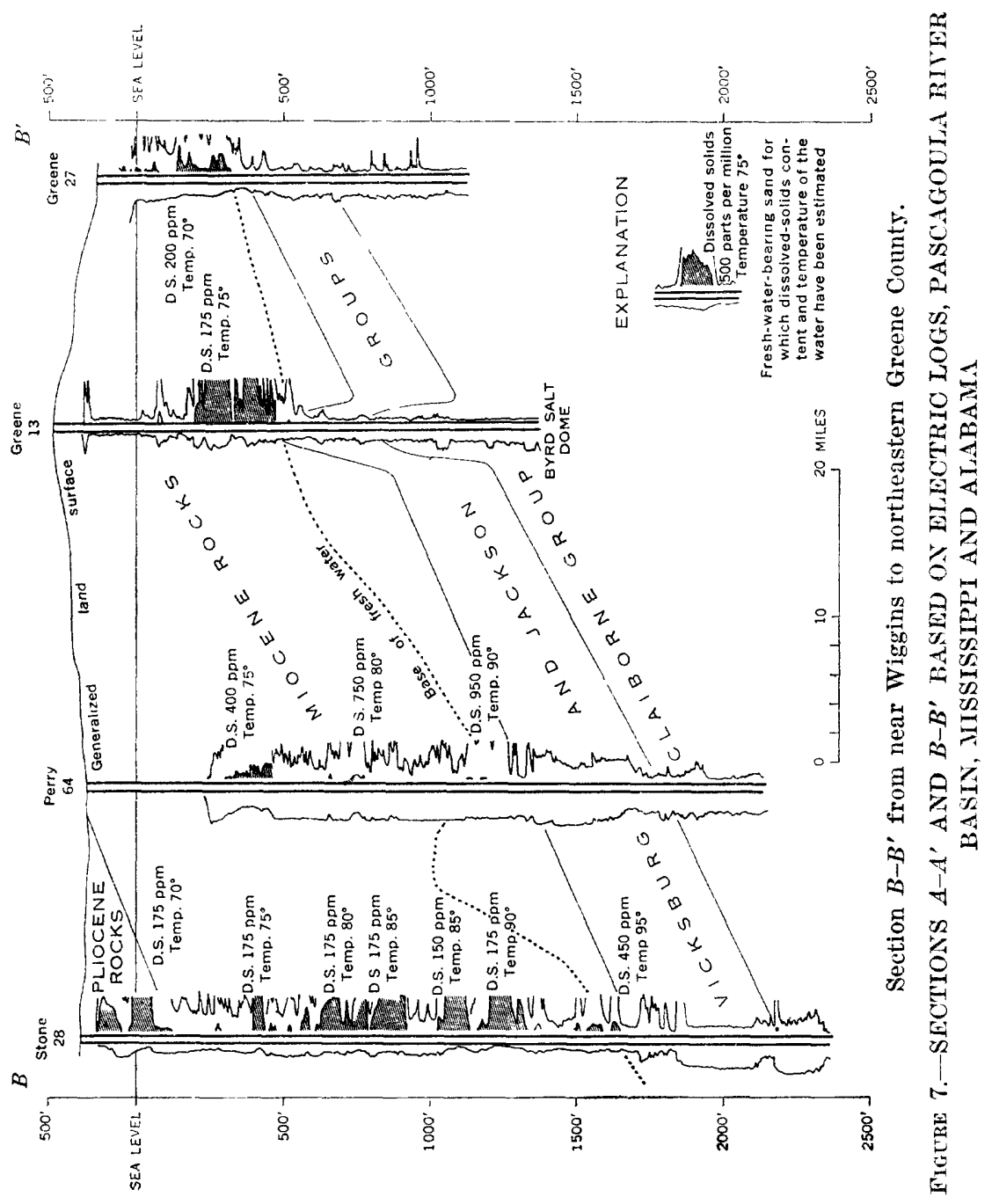




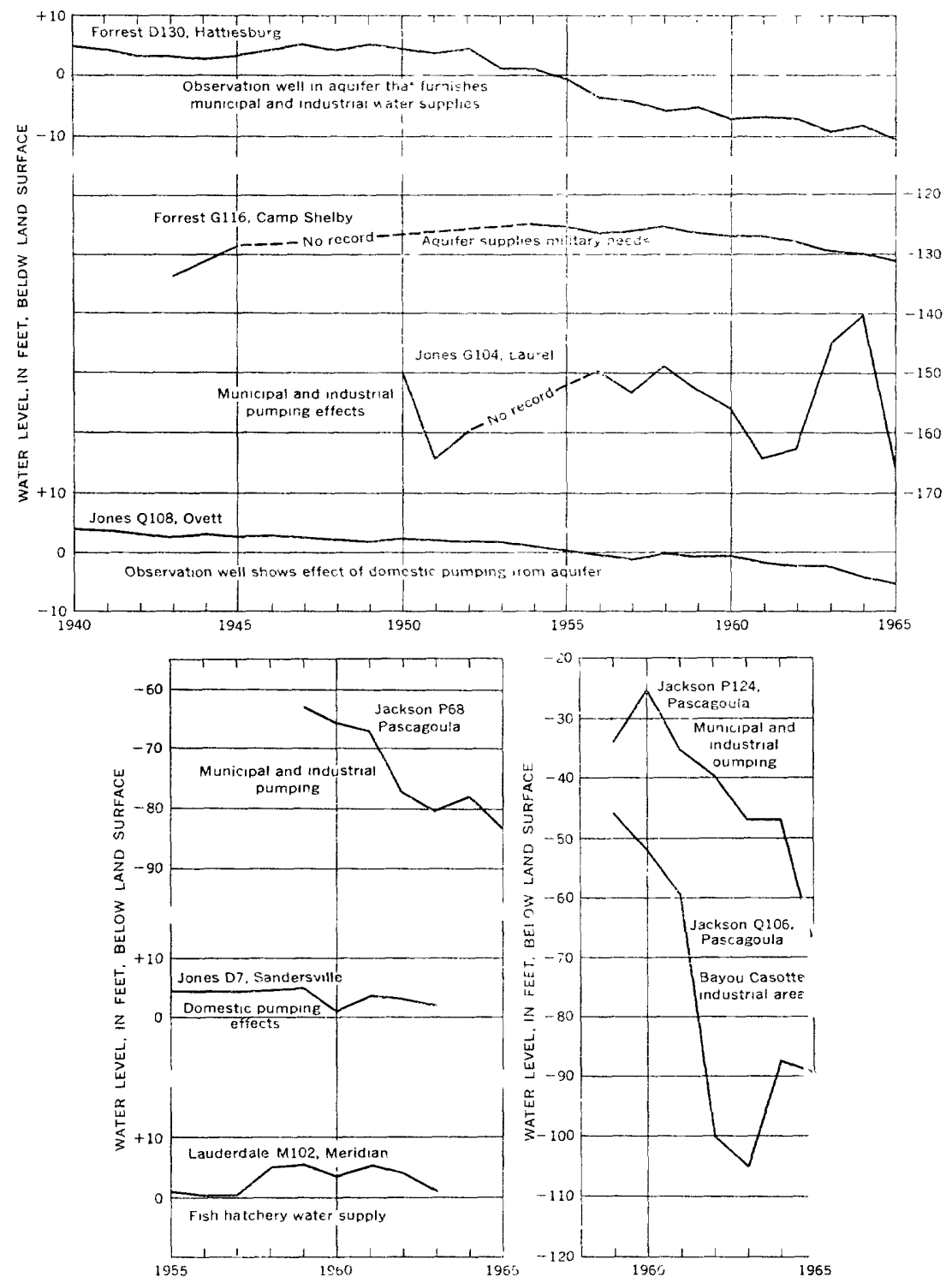

Figure 8.-Water-level trends in selected observation wells. 
Recharge to the ground-water reservoirs in the basin takes place in upland areas where the aquifers crop out or are covered by a thin mantle of permeable sediments of Pliocene and Pleistocene ages. Although the younger formations crop out in the basin and receive recharge there, most recharge to the basal beds of the Wilcox Gro'ip occurs outside the basin in the uplands of Kemper and Neshoba Counties on the north.

Artesian head is imparted to the water as it moves down the grædient in the aquifers and becomes confined between beds of low permeability. Part of the head is lost owing to friction, but that remaining commonly is sufficient to force the water many feet above the land surface where the aquifers are penetrated by wells. This is particularly true of deep aquifers that have undergone little or no development and which contain water under sufficient pressure to cause its rise to 100 feet or more above sea level.

\section{AQUIFER CHARACTERISTICS}

The artesian aquifers of the Pascagoula basin differ greatly in their capacity for transmitting water. Coefficients of transmissibility computed from pumping tests range from 2,800 to $200,000 \mathrm{gpd}$ per ft (gallons per day per foot), and coefficients of storage do not vary much from 0.0001 (table 3). Because the coefficient of transmissibility is the product of the two variables-aquifer thickness and coefficient of permeability - it must be obtained either directly by pumping test or indirectly by multiplying the aquifer thickness by a known or as ${ }^{\prime} u m e d$ coefficient of permeability.

Permeabilities of 110 to $2,250 \mathrm{gpd}$ per sq ft have been determined in the basin; it is probable that these values span the range of permeability for the significant aquifers of the region and most permeability values fall within a range of 300 to 1,000 gpd per sq $\mathrm{ft}$. The limited number of pumping tests available does not permit conclusions on the relative permeability of the water-bearing units. However, the great thickness of many Miocene sand beds implies generally higher transmissibility for that part of the geologic section, and it is transmissibility and available drawdown that determine how much water a well can be expected to yield.

The practical application of measured or assumed aquifer characteristics is in predicting the yields of wells and the effects of ground-water withdrawal. A graph (fig. 9) relating transmissibility to dravdown and well yield is useful in estimating well yields and pump setting. Many of the sand beds listed in table 2 are capable of maintaining well yields in excess of the 2,500-gpm (gallons per minute) limit of the graph; however, not many wells are constructed to supply more than that amount. 


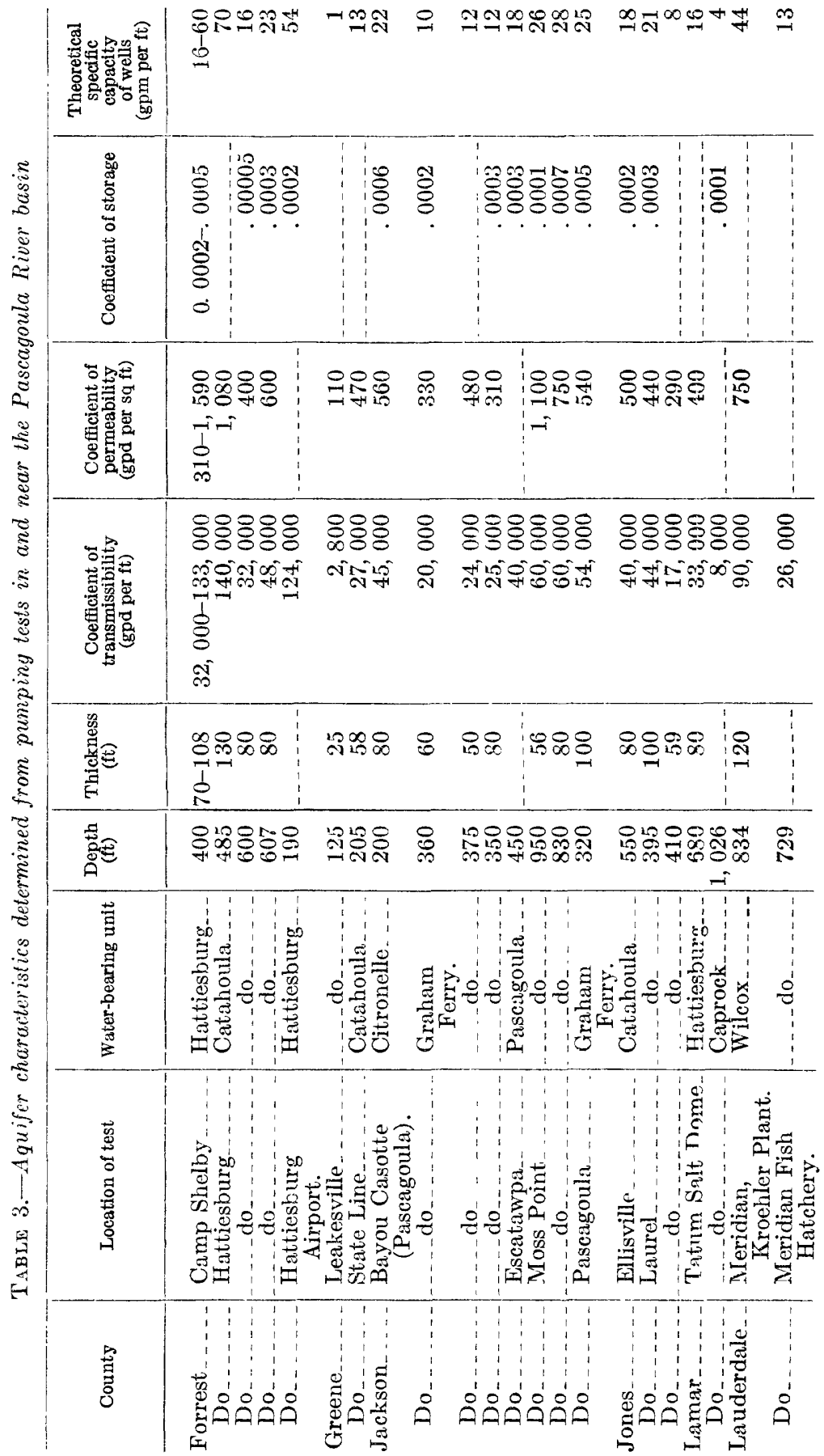




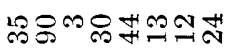

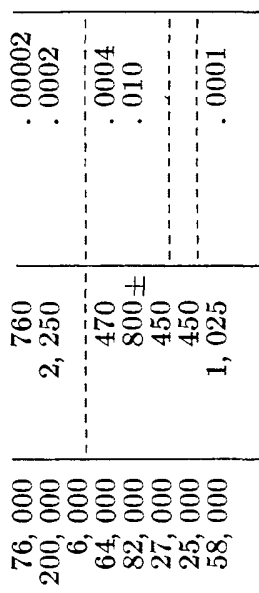

อ̊ำ

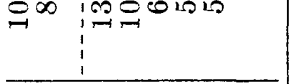

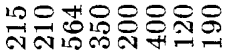

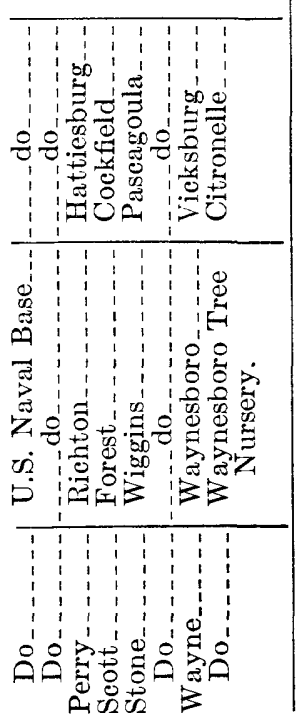




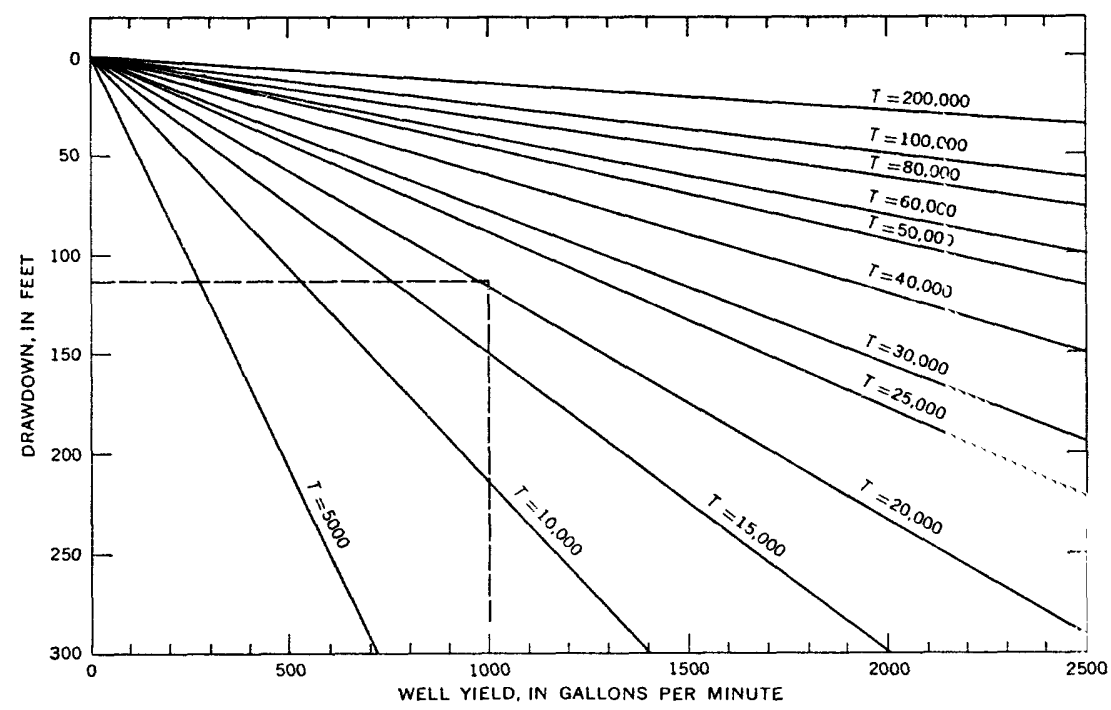

Fraure 9.-Transmissibility-drawdown-yield relation. Where aquifer transmissibility is known or estimated, the chart will provide the drawdowns caused by various pumping rates or the well yields for various amounts of drawdown. Values are based on artesian conditions and on a 100-percent-efficient 12-inch well ; for well efficiencies less than 100 percent, the yield will be decreased or the drawdown increased proportionately. Drawdown computations are based on 1 day of pumping; at 10 days the drawdown would be about 10 percent greater.

\section{An example of the graph's use follows:}

An electric $\log$ of a test hole showed a $40-\mathrm{ft}$ thickness of sand at a depth of $500 \mathrm{ft}$. From other wells tapping that aquifer the static water level is known to be $50 \mathrm{ft}$ below land surface. How deep should a pump be set to supply 1,000 gpm from a 12-in. well?

If the permeability of the aquifer is conservatively figured as 500 gpd per sq $\mathrm{ft}$, the transmissibility would be $20,000 \mathrm{gpd}$ per $\mathrm{ft}(40 \times 500)$. On the graph the $T=20,000$ line crosses the $1,000 \mathrm{gpm}$ line at the 115-fi drawdown line. As the static level is $50 \mathrm{ft}$, a drawdown of $115 \mathrm{ft}$ would place the pumping level at $165 \mathrm{ft}$. This assumes a well with a 100-percent efficiency-one in which no head is lost in movement of water from the aquifer into the well. A fully efficient well is atypical; 75-percent efficiency is more realistic. Therefore it is likely that a pumping level of nearly $200 \mathrm{ft}$ would be requ'red in this example. Of course, any deviation from the assumed permeability or well efficiency will affect the drawdown value.

The effect that pumping the above well would have on tr a artesian pressure surface for the aquifer can also be predicted. A second graph (fig. 10) relates transmissibility and drawdown effect at various times and distances for a selected rate of pumping. This grapl is useful in guiding decisions on well spacing and withdrawal rates. 


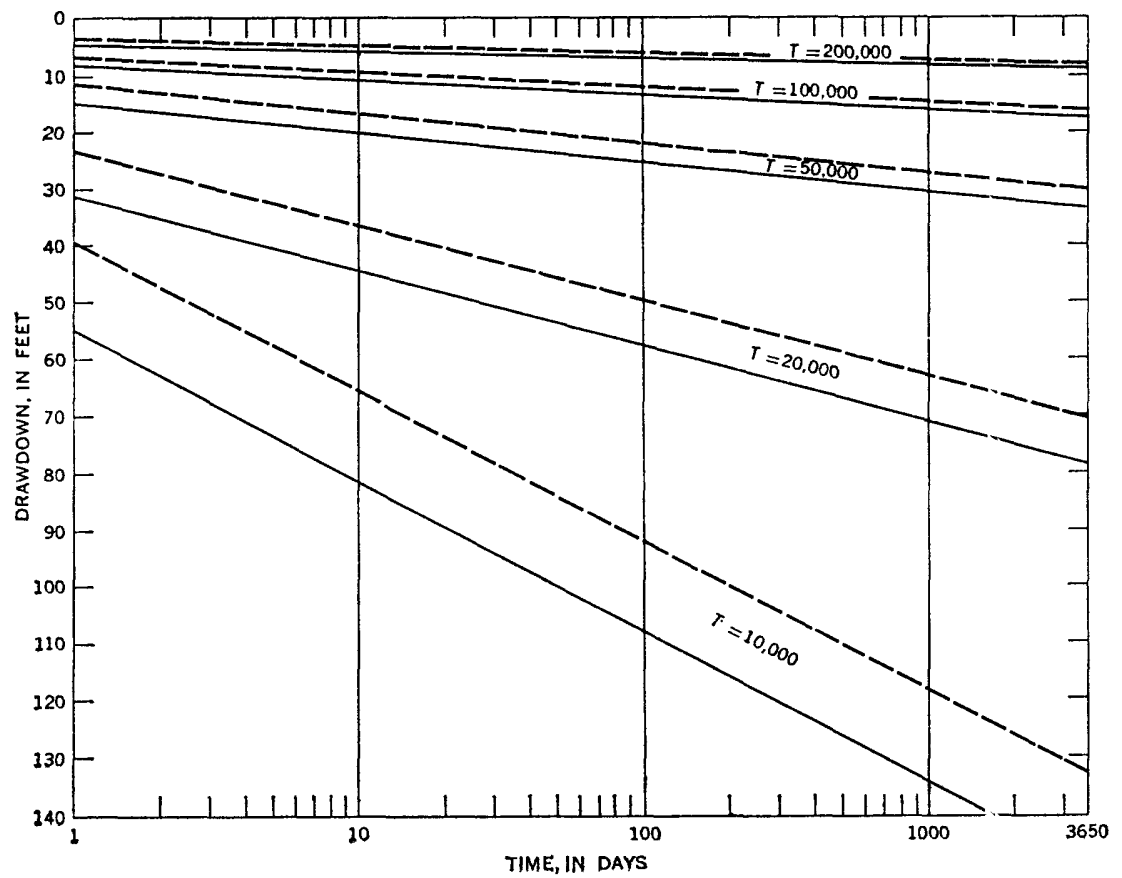

Figure 10.-Time-drawdown relations for selected aquifer characteristics. Pumping rate is $1,000 \mathrm{gpm}$. For other rates the drawdown will be proportional. Solid line represents drawdown at a distance of $\mathbf{5 0 0}$ feet; dashec line, at 1,000 feet from pumped well. $T$ is coefficient of transmissibility in gallons per day per foot. Coefficient of storage is assumed to be 0.0001 .

\section{YIELDS OF WELLS}

Only a few wells in the Pascagoula basin yield more than $590 \mathrm{gpm}$. However, well-yield measurements are ordinarily of little value in appraising an aquifer's capacity to supply water. Wells usually are constructed to provide only the amount of water needed at the time; seldom is the full potential of an aquifer utilized in the wells.

Nearly all the aquifers shown on the sections (fig. 7) are capable of yielding $2,000 \mathrm{gpm}$ or more from properly constructed and fully developed wells. This holds true for most parts of the basin. Figure 7 shows that any aquifer having a coefficient of transmissibility as great as 25,000 gpd per ft could supply $2,000 \mathrm{gpm}$ to a well in which there is as much as 200 feet of available drawdown. Witk higher transmissibility, less drawdown is required.

Well yields must be tailored not only to water-use requirements but to potential effect on the source of supply. Distribution of withdrawal, as to both time and space, must be considered, or even the 
most abundant resource will eventually prove inadequate. Well locations and pumping schedules should be arranged, consistent with economic considerations, so that interference of pumping influence remains at a minimum.

An excellent means of pumpage distribution is available in many places in the Pascagoula basin where more than one aquifer underlies a site. Batteries of wells can be located in a small area and thereby make use of two or more aquifers, provided quality of the water poses no insurmountable problem. In addition, single wells are sometimes screened in two or more separate aquifers; this practice is not always satisfactory, as differences in water level and in aquifer transmissibility favor interchange of water between aquifers to the detriment of well performance.

Using the graphs of figures 9 and 10, one may predict the amount of water that can be obtained in an area of specified size and shape and with a specified maximum drawdown. An example of this prediction is given in the following problem :

Situation: A square plot $1,000 \mathrm{ft}$ on a side ( 23 acres) is available for installation of a well field needed to supply about $13 \mathrm{mgd}$ (million gallors per day). Maximum pumping depth should be no lower than $300 \mathrm{ft}$ below lond surface. An aquifer available at a depth of $500 \mathrm{ft}$ has a coefficient of transmissibility of 50,000 gpd per $\mathrm{ft}$ and a coefficient of storage of 0.0001 . The static water level is $20 \mathrm{ft}$ below average land surface.

Information desired: How many wells are needed, what should be their pumping rate, and how should they be spaced?

Answer: Eight fully efficient wells pumped at 1,125 gpm each ard arranged around a 1,000-ft square on 500-ft centers. The greatest drawdown at the end of 1 year would be $274 \mathrm{ft}$ ( 294 below land surface). This well field would supply $12.95 \mathrm{mgd}$. Water levels will be drawn down substantially in the area adjacent to the well field; however, the effects will decrease as distance from the well field increases.

\section{PUMPAGE}

\section{PRESENT}

Total ground-water pumpage in the Pascagoula River basin is estimated to be $60 \mathrm{mgd}$ in 1965 . Centers of heaviest withdrawal are Hattiesburg ( $8 \mathrm{mgd}$ ), Laurel (9 $\mathrm{mgd}$ ), Meridian (5 mgd), and Pascagoula $(11 \mathrm{mgd})$. Practically all domestic and municipal rater supplies and most industrial supplies are obtained from the gro'und-water reservoir. A notable exception is the water supply of the International Paper Co. at Escatawpa where $45 \mathrm{mgd}$ of water from the Escatawpa River is delivered by a pipeline 13 miles long. The city of Mobile, although outside the Pascagoula River basin, uses about $100 \mathrm{mgd}$ from the Big Creek Reservoir, which is in the Fiscatawpa River subbasin. 
Potental

It is probable that nowhere in the Pascagoula basin has pumpage reached the point that no further development can be wisely undertaken in the general vicinity. Even in places where substantial drawdown of the water level has occurred, areal redistribution of pumpage or tapping of deeper aquifers offers remedies for local overdevelopment.

On the basis of known aquifer thicknesses and assumed hydraulic characteristics, ground-water supplies as large as $25 \mathrm{mgd}$ can be obtained in 1-square-mile areas at several localities in the region. Of course, recovery of such quantities through wells may not be economically feasible everywhere because of limitations on size and, th arefore, discharge of individual wells and pumps.

\section{MFFECTS}

The effect of pumpage on water levels has been covered in preceding sections, and the effect of pumpage on quality of the water is erplained in the following section. However, one effect of pumpage that receives little attention, possibly because it is of a positive nature, is the diversion-toward the center of withdrawal-of ground water that would normally flow through and around the area of pumping influence. In effect, the deeper the pumping water level is lowered, the farther out the cone of influence that funnels water toward tro center of withdrawal is extended. As the cone of influence approaches an area of recharge to the aquifer, surface water that would have been rejected by a full aquifer is received instead, enters the aquifer, and replaces the water pumped out.

Water cannot be pumped without lowering the water level. The ideal situation is one in which the lowering of pumping water levels does not result in excessive pumping costs and is at the same time great enough to induce inflow from an area of substantial size-one which will insure the longevity of the well field.

\section{ARTIFICIAL RECHARGE}

Artificial recharging of aquifers for raising water levels, preventing salt-water encroachment, and disposing of waste water is fensible in the Pascagoula basin. In addition, water spreading to flush saline water from coastal terrace aquifers and for storage has received some consideration in recent years. The objectives of most artificial-recharge operations are to maintain or reestablish water levels and to maintain or improve water quality. Therefore, disposal of clenn waste water into aquifers and storage of water in one season for use in another season are to be encouraged in most circumstances. 


\section{SALINE-WATER RESOURCES}

Saline-water aquifers are used only as disposal receptacles for oilfield brine at present. Saline water in the ground should be considered as a resource. Industrial processes that can tolerate saline water are far from unknown. Advances in desalination imply a dofinite potential for the resource. An obvious question of the inland water planner is : "Why desalt and transport sea water, which contains about $35,000 \mathrm{ppm}$ dissolved solids, when water of lower salinity is available beneath our feet?" In addition, the byproducts that might be made available in desalination of ground water are potentially of value.

The contour map (fig. 11) was constructed to show the approximate elevation of the uppermost significant saline-water aquifers. Comparing this map with figure 4 shows that the saline aquifers are in general 2,000 to 4,000 feet deeper than the base of fresh water. Intervening beds consist chiefly of clay, silt, and consolidated rock. There are sand beds in the interval, but they are mostly thin and not considered to represent substantial sources of water.

Artesian pressure in the saline-water aquifers probably is sufficient to force the water to elevations at least 200 feet above sea level.

\section{QUALITY OF THE WATER}

CHEMICAT CHARACTER

Ground water of good to excellent quality is available throughout the basin. In places the near-surface aquifers contain somewhat corrosive water, which results in excessive concentrations cf iron in the water; but deeper zones in the same localities provide satisfactory supplies. The water is chiefly a sodium bicarbonate type. It is generally soft and low to moderate in dissolved-solids concentration. The chemical analyses in table 4 represent ground water from all parts of the Pascagoula basin (fig. 12).

The water is suitable for practically all uses, although weter in the deeper aquifers usually has a percent sodium exceeding the desirable limits for irrigation water. Little treatment is applied ordinarily for municipal and industrial uses. Aeration facilities to permit the escape of carbon dioxide, and thus raise the $\mathrm{pH}$, is the treatment most commonly applied. Iron removal often accompanies aeration.

Estimates of the dissolved-solids concentration in water in the deep untapped aquifers can be made where electrical resistivity of the water in the formations is recorded by electric logs. Predicted values obtained from this source are given opposite the aquifer intervals on the sections (fig. 7). The deepest extent of fresh water (fig. 4) is also determined in this manner. 


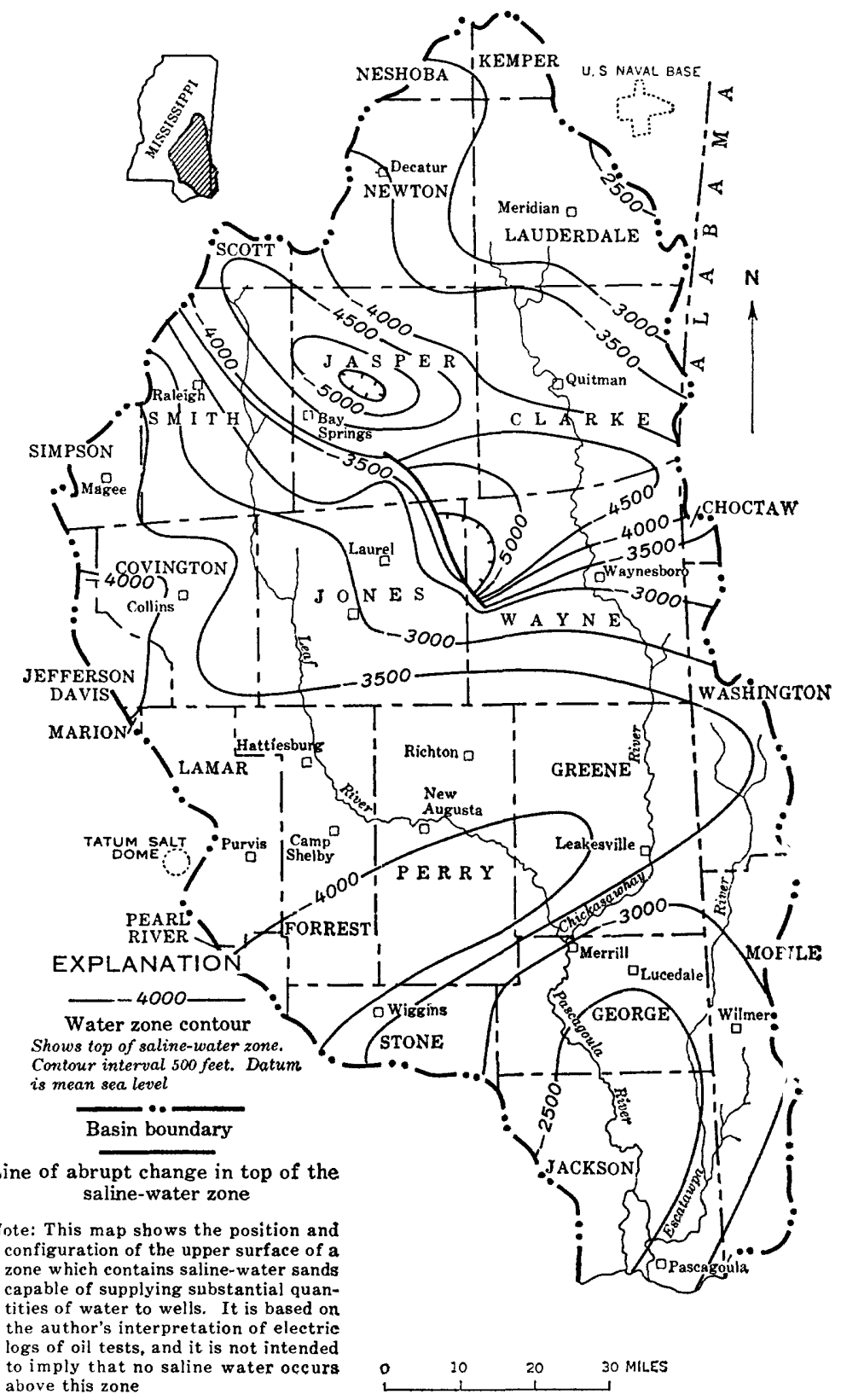

FTGURE 11.-Configuration of the top of the saline-water-resource zone. 


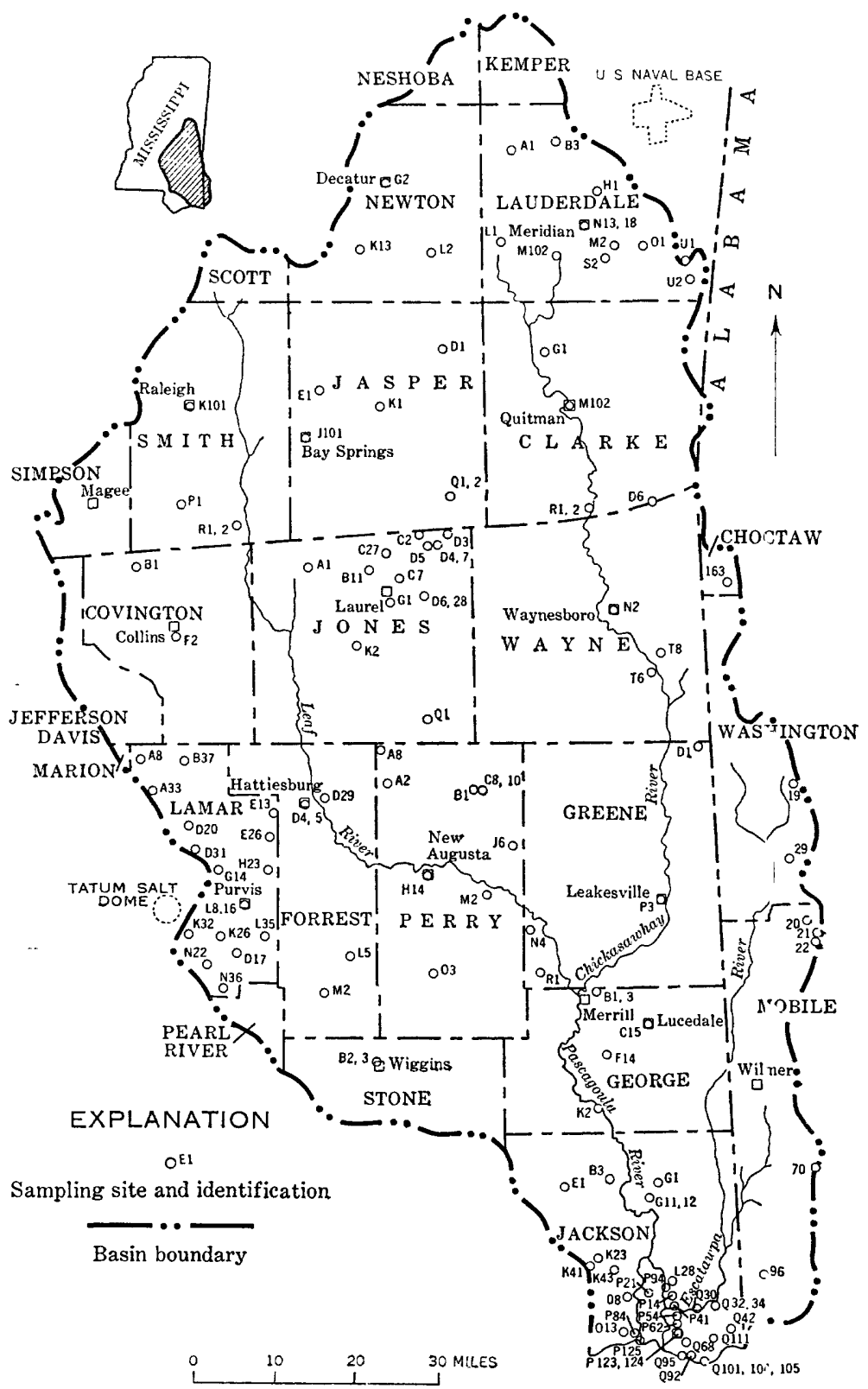

FIgURe 12.-Location of water-sampling sites. Chemical analyses in table 4. 
Typically, the ground water of the basin is more highly mineralized than water in the surface streams; however, it is constant in quality and temperature, and turbidity is not a problem. Depending upon the needs of the user, ground water or surface water or a combination of the two would satisfy almost any chemical-quality requirements.

\section{SALT-WATER ENCROACHMENT}

All the artesian aquifers contain salty water at depth. Heavy pumping that reduces artesian pressure permits the gradual updip movement of the interface between fresh water and salt water. Similarly, in the tidal area near the coast, heavy pumping from water-table aquifers in the surface deposits would induce inflow of brackish water from the estuarine streams.

Other causes of salt-water contamination of aquifers are disposal of industrial wastes by injection into fresh-water zones and incomplete plugging of wells that enter the salt-water zone and permit the upward flow of salt water from that zone.

Salt-water encroachment has become noticeable in a few places along the Gulf Coast (Lang and Newcome, 1964). The Pascagoula Formation now yields water of marginal quality to some wells in Pascagoula. Chloride concentrations in water from wells screened in the Graham Ferry Formation in the Pascagoula area generally exceed $100 \mathrm{ppm}$ (Newcome and Golden, 1964); but the rate of encroachment is very slow and, in some monitor wells, no increase in chloride content has been observed in the 5 years preceding this report.

\section{WATER TEMPERATURE}

Ground water in shallow aquifers (50- to $150-\mathrm{ft}$ depths) in the Pascagoula basin has a temperature of about $66^{\circ} \mathbf{F}$. From th is, the temperature rises $1^{\circ} \mathrm{F}$ for every 55 - to 60 -foot increase in depth. The measured temperature of the discharge from a 1,200-foot well at Gulfport was $86^{\circ}$. Farther west, in Hancock County, the temperature of water from a depth of 1,875 feet was $100^{\circ}$.

Accurate aquifer-temperature measurements are difficult to obtain. It has been found that the temperature of water from deep wells can be measured reliably at the surface only if the flow or pump yield is sufficient to overcome the cooling effect of lower temperatures at shallow depth outside the wells. Discharges of $100 \mathrm{gpm}$ or more are desirable to insure representative aquifer-temperature data.

Ground-water temperature is constant the year around. The resource thus can be used for either cooling or heating, as well as for constant-temperature processes. 


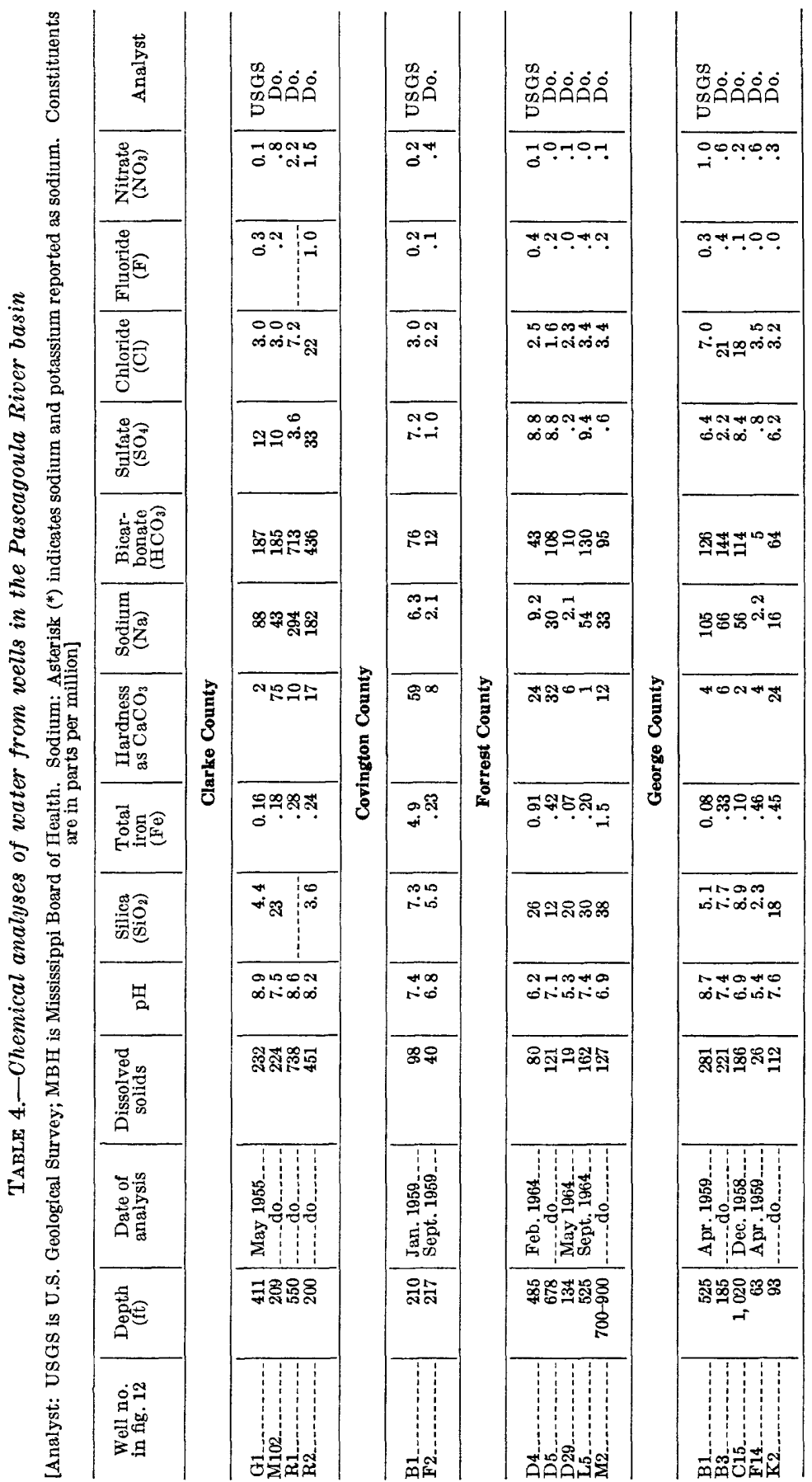




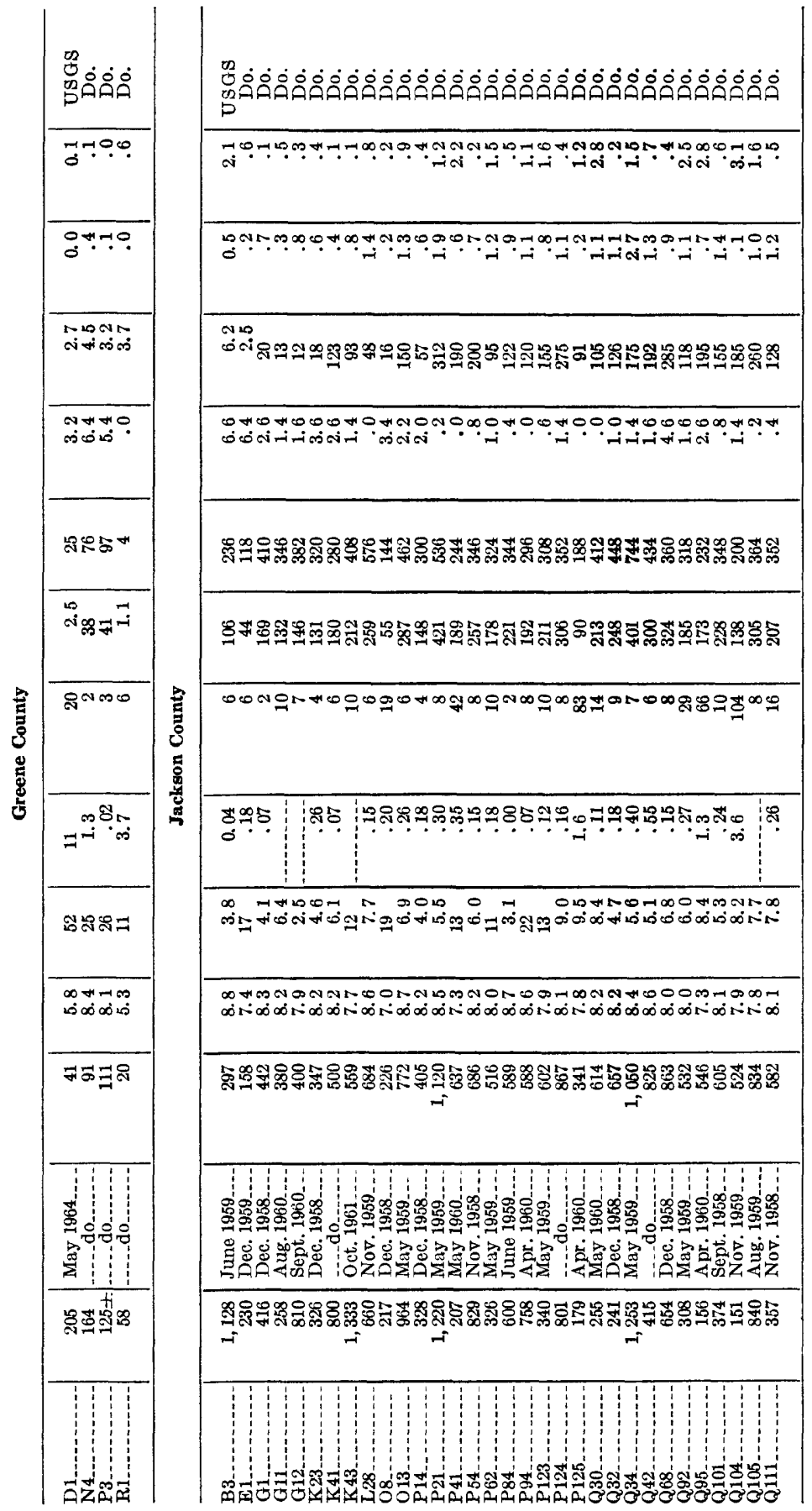



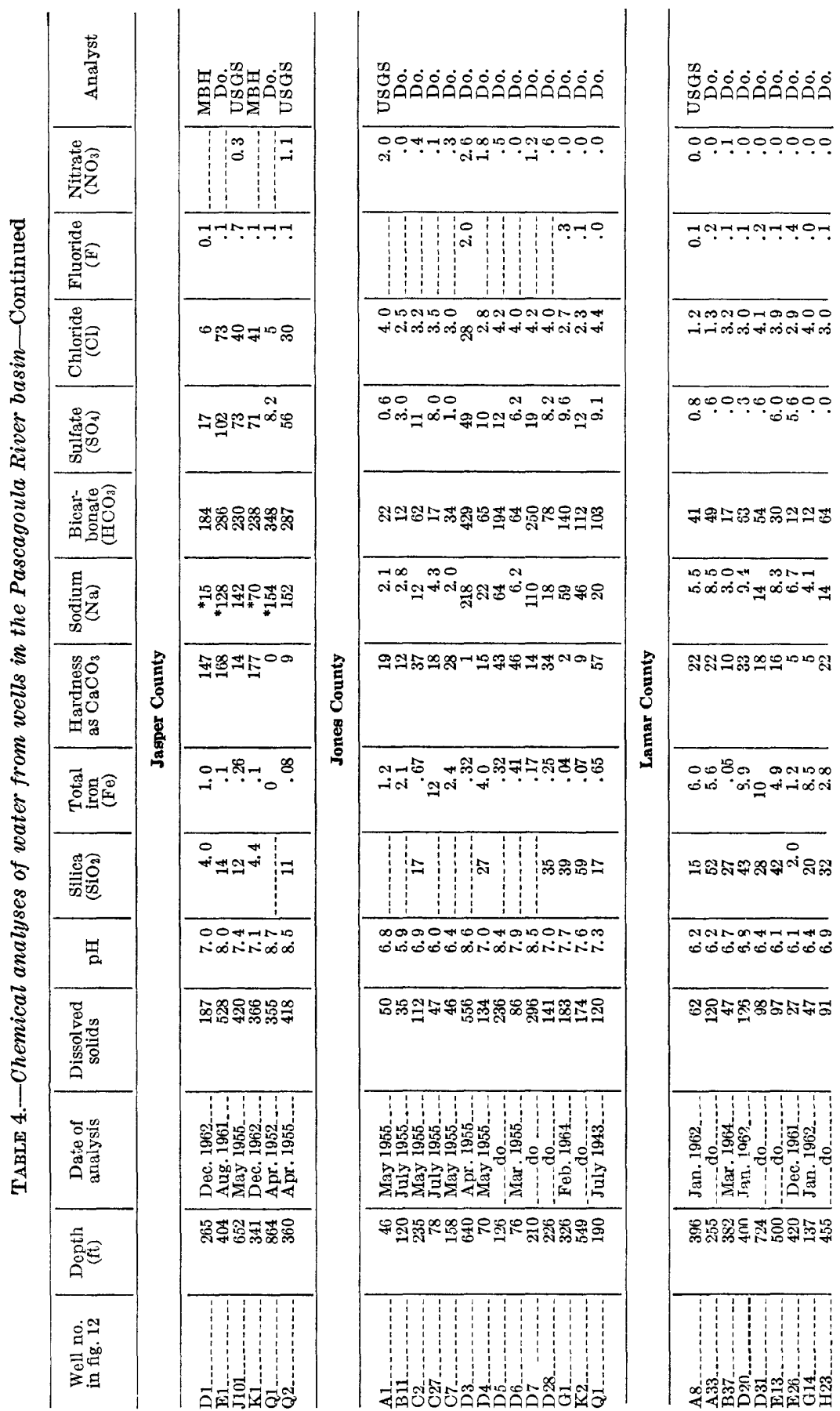


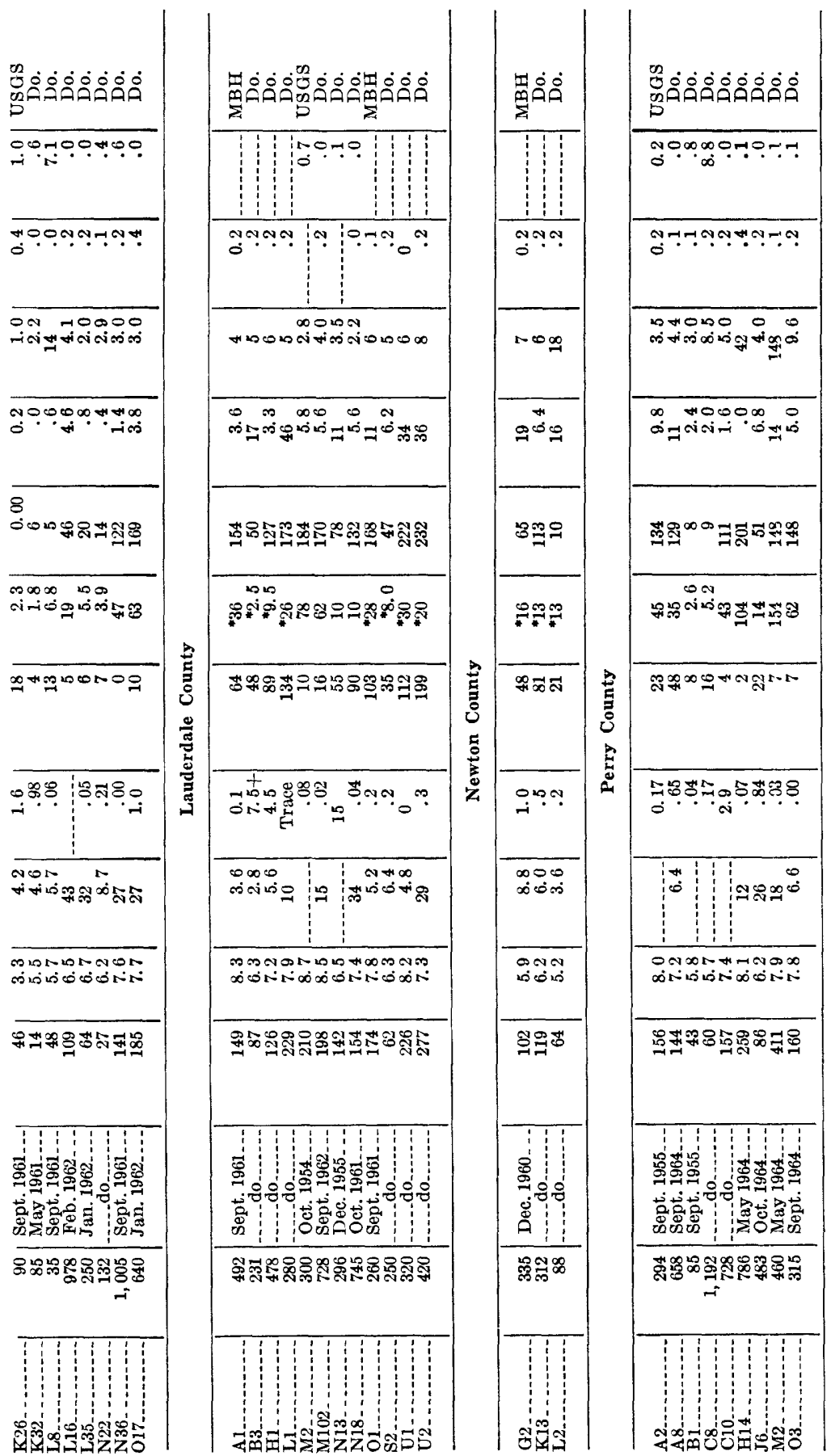


K34 CONTRIBUTIONS TO THE HYDROLOGY OF THE UNISED STATES

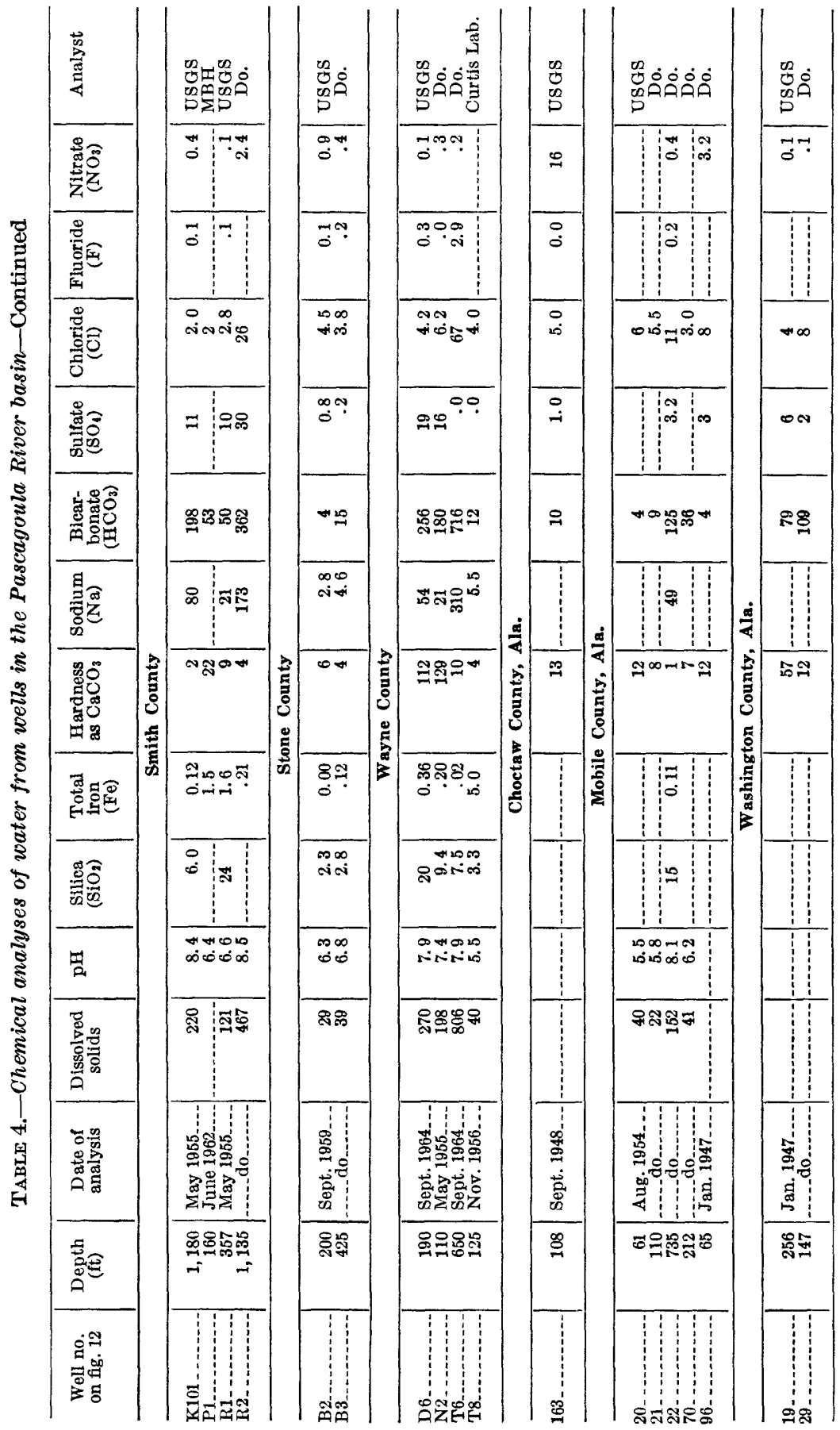




\section{CONCLUSIONS}

Abundant ground-water resources underlie the Pascagoula River basin. Present water-supply developments tap only a small faction of the quantity available to wells. Efficient use of the resource requires (1) tapping of thick aquifers deeper than present wells, (2) construction of efficient large-capacity wells, and (3) proper spacing of wells to avoid excessive interference.

With careful programs of exploration and development, it should be possible to obtain water supplies as great as $25 \mathrm{mgd}$ in many localities. Individual well yields of $2,000 \mathrm{gpm}$ could become commonplace, and yields of $5,000 \mathrm{gpm}$ are not unreasonable to expect in some pleces.

Quality of the ground water is adequate for practically all uses, although suitable supplies for irrigation will not be as readily obtainable as those for other purposes because of the natural predominance of water of a sodium bicarbonate type.

In the interest of optimum development of the ground-water resources, as well as their conservation, it is desirable that the potential effects of engineering works on the ground-water reservoirs ks evaluated. The extent of manmade effects ordinarily can be determined only by detailed studies of the hydrologic environment in the loalities concerned.

\section{SELECTED REFERENCES}

Brown, G. F., 1944, Geology and ground-water resources of the Camr Shelby area: Mississippi State Geol. Survey Bull. 58, 72 p.

Brown, G. F., and other's, 1944, Geology and ground-water resources of the coastal area in Mississippi : Mississippi State Geol. Survey Bull. 60, 229 p.

Golden, H. G., 1959, Temperature observation's of Mississippi streams : Mississippi Board Water Commissioners Bull. 59-1, 67 p.

Harvey, E. J., 1963, Compilation of aquifer test data for Mississippi : Miøsissippi Board Water Commissioners Bull. 63-4, 10 p.

Harvey, E. J., and Shows, T. N., 1963, Well records, logs, and water snalyses, George and Jackson Counties, Mississippi : Mississippi Board Water Commissioners Bull. 63-1, 43 p.

Harvey, E. J., Golden, H. G., and Jeffery, H. G., 1965, Water resources of the Pascagoula area, Mississippi : U.S. Geol. Survey Water-Supply Paper 1763, $135 \mathrm{p}$.

Humphreys, C. P., Jr., 1963, Floods of 1959 in Mississippi : Mississipri Board Water Commissioners Bull. 63-8, 19 p.

Kapustka, S. F., Harvey, E. J., and Hud'son, J. W., 1963, Water resourc 3 investigations during fiscal year 1963, Jackson County, Mississippi : Mississippi Board Water Commissioners Bull. 63-7, 11 p.

Lang, J. W., and Robinson, W. H., 1958, Summary of the water resources of the Hattiesburg, Laurel, and Pascagoula areas, Mississippi : Mississippi Board Water Commissioners Bull. 58-2, 16 p.

Lang, J. W., and Newcome, R., Jr., 1964, Status of salt-water encroacl ment in aquifers along the Mississippi Gulf Coast-1964: Mississippi Board Water Commissioners Bull. 64-5, 17 p. 
Newcome, R. Jr., and Golden, H. G., 1964, Status of water resources in Jackson County, Mississippi-fiscal year 1964: Mississippi Board Water Commissioners Bull. 63-4, $17 \mathrm{p}$.

Robinson, W. H., and Skelton, J., 1960, Minimum flows at stream-gaging stations in Mississippi : Mississippi Board Water Commissioners Bull. 60-1, 91 p.

Shows, T. N., and Golden, H. G., 1964, Water resources studies in southeast Mississippi: U.S. Geol. Survey open-file rept., 9 p.

Skelton, J., 1961, Low-fiow measurements at selected sites on streams in Mississippi : Mississippi Board Water Commissioners Bull. 61-1, 13: p.

Stephenson, L. W., Logan, W. N., and Waring, G. A., 1928, Gronnd-water resources of Mississippi, with discussions of the chemical character of the waters, by C. S. Howard: U.S. Geol. Survey Water-Supply Parer 576, 515 p.

U.S. Geological Survey, 1964, Surface water records of Mississippi-1963: Water Resources Division, $107 \mathrm{p}$.

Wilson, K. V., 1963, Floods of 1960 in Mississippi : Mississippi Board Water Commissioners Bull. 63-9, 9 p. 